\title{
Salinization of groundwater in the Nefzawa oases region, Tunisia Results of a regional-scale hydrogeologic approach
}

\author{
Journal Article \\ Author(s): \\ Zammouri, Mounira; Siegfried, Tobias; El-Fahem, Tobias; Kriâa, Samiha; Kinzelbach, Wolfgang \\ Publication date: \\ 2007-11 \\ Permanent link: \\ https://doi.org/10.3929/ethz-b-000004729 \\ Rights / license: \\ In Copyright - Non-Commercial Use Permitted \\ Originally published in: \\ Hydrogeology Journal 15(7), https://doi.org/10.1007/s10040-007-0185-x
}




\title{
Salinization of groundwater in the Nefzawa oases region, Tunisia: results of a regional-scale hydrogeologic approach
}

\author{
Mounira Zammouri • Tobias Siegfried • \\ Tobias El-Fahem • Samiha Kriâa • \\ Wolfgang Kinzelbach
}

\begin{abstract}
Groundwater pumped from the semi-confined Complexe Terminal (CT) aquifer is an important production factor in irrigated oases agriculture in southern Tunisia. A rise in the groundwater salinity has been observed as a consequence of increasing abstraction from the aquifer during the last few decades. All sources of
\end{abstract}

Received: 4 January 2006/Accepted: 29 March 2007

Published online: 5 May 2007

(C) Springer-Verlag 2007

\section{Zammouri}

Ecole Superieure des Ingénieurs de l'Equipement

Rural de Medjez el Bab,

Route du Kef, Km 5,

9070, Medjez el Bab, Tunisia

e-mail: z_mounira@yahoo.fr

T. Siegfried $\cdot$ W. Kinzelbach

Institute of Environmental Engineering,

Swiss Federal Institute of Technology,

Wolfgang-Pauli Strasse 15,

CH-8093, Zürich, Switzerland

\section{T. El-Fahem}

Institute of Geology, University of Bonn,

Nussallee 8 ,

53115, Bonn, Germany

\section{S. Kriâa}

Laboratoire de Modélisation en Hydraulique et Environnement, Ecole Nationale d'Ingénieurs de Tunis,

B.P.37 le Belvédère 1002,

Tunis, Tunisia

Present address:

T. Siegfried ( $\square)$

Earth Institute, Columbia University in the City of New York,

500 W. 120th St. Room 842A,

New York, NY 10027, USA

e-mail: ts2392@columbia.edu

Tel.: +1-212-8541695

Fax: +1-212-8547081

Present address:

T. El-Fahen

AOC-Cellule Opérationnelle d'AMMA, IRD-Representation,

01 B.P. 4414, Cotonou, Bénin

\section{Present address:}

S. Kriâa

Entreprise Tunisienne d'Activités Pétrolières,

27 bis, Avenue Kheireddine Pacha,

1002, Bélvèdére, Tunis contamination were investigated using hydrochemical data available from the 1980s. Water samples were taken from drains and observation wells tapping both the CT and the phreatic aquifers and analyzed with regard to chemistry, temperature, isotopes and other environmental tracers. Local salinization mechanisms are suggested, i.e. the upwelling of saline water from the underlying, confined Continental Intercalaire (CI) aquifer, as well as backflow of agricultural drainage water. At this stage, the main salt pan, the Chott el Djerid, is not a contamination source. A finite difference model was also developed to simulate groundwater flow and contaminant transport in the oases. Calibration for the period 1950-2000 was carried out in order to adjust geological and chemical system parameters. The simulation of planned extraction projects predicts a worsening of the present situation. Maintenance of the present abstraction regime will not reduce or stop the salinity increase.

Résumé L'eau souterraine pompée dans l'aquifère semicaptif du Complexe Terminal (CT) est un facteur de production important pour l'agriculture des oasis irriguées du sud de la Tunisie. Une augmentation de la salinité de l'eau souterraine a été considérée comme la conséquence de l'augmentation des prélèvements dans l'aquifère au cours des dernières décades. Toutes les sources de contamination ont été étudiées à l'aide de données hydro-chimiques disponibles depuis les années 80 . Des échantillons d'eau ont été prélevés dans des drains et des puits d'observation qui captent à la fois le CT et les aquifères phréatiques; la chimie, la température, les isotopes ainsi que d'autres traceurs environnementaux ont été analysés. Des processus locaux de salinisation sont proposés, comme par exemple la remontée d'eau salée en provenance de l'aquifère captif du Continental Intercalaire (CI) sous-jacent, ainsi que le reflux des eaux du drainage agricole. A ce stade, le principal marais salé, le Chott el Djerid, n'est pas une source de contamination. Un modèle aux différences finies a également été élaboré pour simuler les écoulements souterrains et le transport de contaminants dans les oasis. Une calibration pour la période 1950-2000 a été effectuée afin d'ajuster les paramètres des systèmes géologique et chimique. La simulation de projets planifiés d'extraction prédit une aggravation de la situation actuelle. La conservation du régime d'extraction actuel ne réduira ou ne stoppera pas l'augmentation de la salinité. 
Resumen El agua subterránea que se bombea del acuífero semi-confinado Terminal Complejo (CT) es un importante factor de producción en la agricultura de riego con oasis en el sur de Túnez. Se ha observado un incremento en la salinidad del agua subterránea como consecuencia de la abstracción creciente del acuífero durante las últimas décadas. Se investigaron todas las fuentes de contaminación usando datos hidroquímicos disponibles de la década de 1980s. Las muestras de agua se tomaron de drenajes y pozos de observación alojados tanto en el CT como los acuíferos freáticos y se analizaron en relación con química, temperatura, isótopos y otros trazadores ambientales. Se sugieren mecanismos de salinización local, i.e. el ascenso de agua salada a partir del acuífero confinado subyacente Intercalado Continental (CI), así como también retorno de flujo de agua de drenaje agrícola. En esta etapa, el pan salado principal, el Chott el Djerid, no es una fuente de contaminación. También se desarrolló un modelo de diferencia finita para simular el flujo de agua subterránea y el transporte de contaminantes en los oasis. Se calibró el modelo para el periodo 1950 2000 para de este modo ajustar parámetros del sistema químico y geológico. La simulación de los proyectos de extracción que se han planeado predice un empeoramiento de la situación actual. El mantenimiento del régimen de extracción actual no reducirá o detendrá el incremento de salinidad.

Keywords Arid regions · Groundwater management . Hydrochemistry · Numerical modeling · Salinization

\section{Introduction}

The negative effects of groundwater mining are observed globally. They threaten future water supply locally. Especially in semiarid to arid regions, where aquifers are the sole freshwater resource, this is problematic and can lead to an excessive rise in the cost of provision and can hamper economic productivity of irrigated agriculture. Both soil salinization and groundwater quality degradation are the main threats to sustainable utilization of natural resources. For example, globally, it is estimated that approximately 77 million ha or about one third of irrigated land is affected by salinization to varying degrees (Gardner 1996). The Sahara oases of northern Africa are no exception (Ghassemi et al. 1995).

The process of soil salinization consists of an accumulation of salt in the productive root zone of the soil. It is caused by the increased salinity of phreatic aquifers and rising groundwater levels that result, due to the application of excess irrigation water as well as insufficient drainage of soils (WHO-ENEP 1989). If no adequate measures are taken, complete soil sterilization will result together with a loss of yield. Mitigation measures include the application of excess water so as to flush the soil as well as the extension and/or improvement of drainage systems. However, the former technique is only applicable if the latter is ensured. Otherwise, shallow water tables will rise at an even faster pace and further aggravate the situation (Hillel 2000). Economic resilience to such adverse development in groundwater resources is weak where natural assets, including productive soil and freshwater as well as capital, are scarce. Therefore, proper resource management in these areas is crucial.

One such location is the Nefzawa oases region in southern Tunisia situated at the northern fringe of the Saharan Platform (see Fig. 1). Here, the climate is arid to hyper-arid with less than $100 \mathrm{~mm} / \mathrm{a}$ of rainfall with high temporal and spatial variability. Daily mean temperatures vary between $10^{\circ} \mathrm{C}$ in the winter to $32^{\circ} \mathrm{C}$ in the summer with August being the hottest month. Yearly open water evaporation is on the order of 2,500 mm (El-Fahem 2003; Mamou 1990). The Nefzawa oases region is famous for the production of the high-quality Deglet Nour date. At the turn of the century, Tunisia was selling more than 20,000 metric tonnes $(20,000,000 \mathrm{~kg})$ on the world market, which accounted for more than half of the total dates export of Africa or $10 \%$ of the total Tunisian agricultural export market value (FAO 2005).

Apart from the export of cash crops and fuelled by rising population numbers $\left(4.3 \times 10^{6}\right.$ in $1960,9.8 \times 10^{6}$ in 2003 (The World Bank Group 2004), agricultural policy in Tunisia in the last 50 years was determined by considerations of food security, self-sufficiency and import substitution practices (Perennes 1993). As a result, the irrigated area has increased by a factor of four over the same period of time (OSS 2003). In the year 2000, it

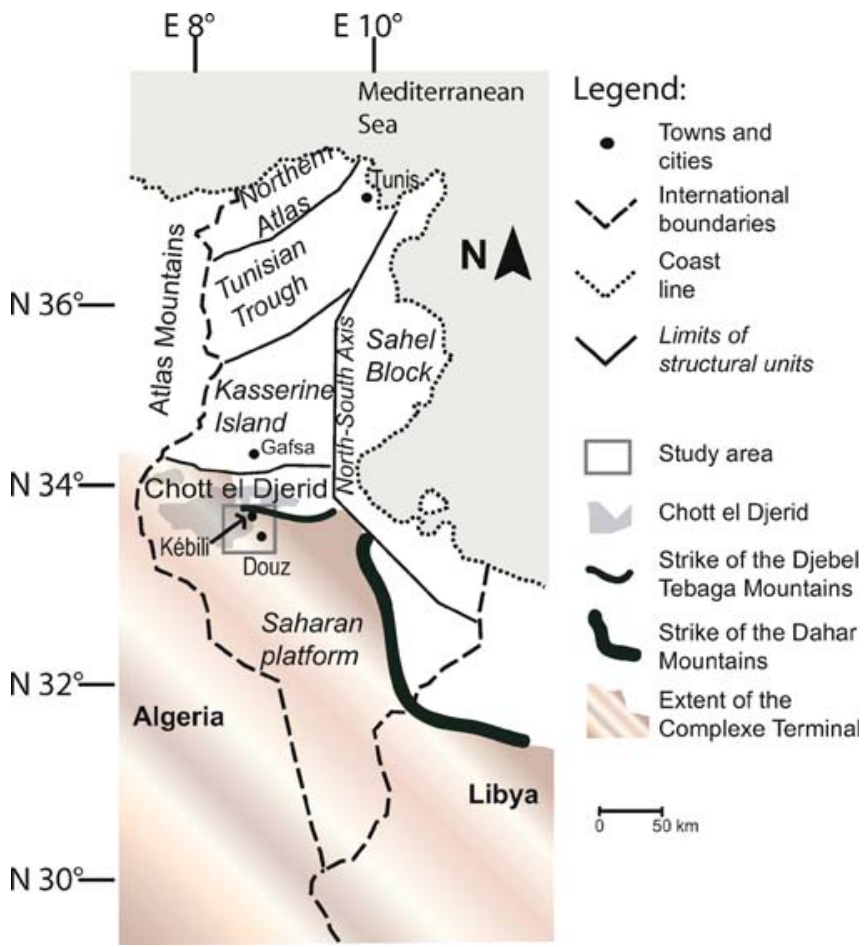

Fig. 1 Location of the project area in southern Tunisia (modified after Swezey 1996). The square box delineates the flow and transport model domain. Figure 2 shows a detailed map of the Nefzawa oases region 
extended over an area of more than 381,000 ha (FAO 2005). This expansion was mainly accomplished by the large-scale allocation of fossil groundwater resources from the Complexe Terminal aquifer (CT) and the underlying Continental Intercalaire aquifer (CI). It involved a gradual transition from traditional groundwater abstraction from hand dug wells or springs to high-volume abstraction by motor pumps and from deep artesian wells. The technological transition was governmentally supported.

Until 1907, exploitation of the CT in the area of the Nefzawa oases was accomplished by utilizing discharge from natural springs (see Fig. 2 for their location). These springs were fed by artesian water from the CT. The first deep well with artesian outflow was drilled in 1907. From the 1950s onwards, the flow from the natural springs diminished because of the continuous lowering of the piezometric level by the installed artesian wells. Deep wells were gradually equipped with pumps after 1970 . Figure 3 shows the water quantities extracted from the CT between 1950 and 2002. The total abstraction increased more than sevenfold from $1.4 \mathrm{~m}^{3} / \mathrm{s}$ in 1950 to $10.5 \mathrm{~m}^{3} / \mathrm{s}$ in 2002. The natural outflow of the springs reached $0.5 \mathrm{~m}^{3} / \mathrm{s}$ in 1950 and had practically vanished by 1995 . Exploitation through pumping increased from $0.5 \mathrm{~m}^{3} / \mathrm{s}$ in 1976 to $2.7 \mathrm{~m}^{3} / \mathrm{s}$ in 2002 . The installation of the so-called "illicit" deep wells brought another notable, yet governmentally unauthorized, increase in exploitation. These wells belong to private farmers settling in the vicinity of existing oases. There, they reclaim land and extract water from privately funded wells. At the present time, exploitation by illicit wells exceeds that by officially approved wells. Illicit abstraction rose from only $0.025 \mathrm{~m}^{3} / \mathrm{s}$ in 1981 to about
Fig. 2 Overview of the Nefzawa oases region. Important oases are highlighted. The chemical cross sections are shown in Fig. 6. Complexe Terminal piezometric levels in 1988 are shown (after Mamou 1990). Map Projection: UTM, Date: WGS 84, Zone: S 32

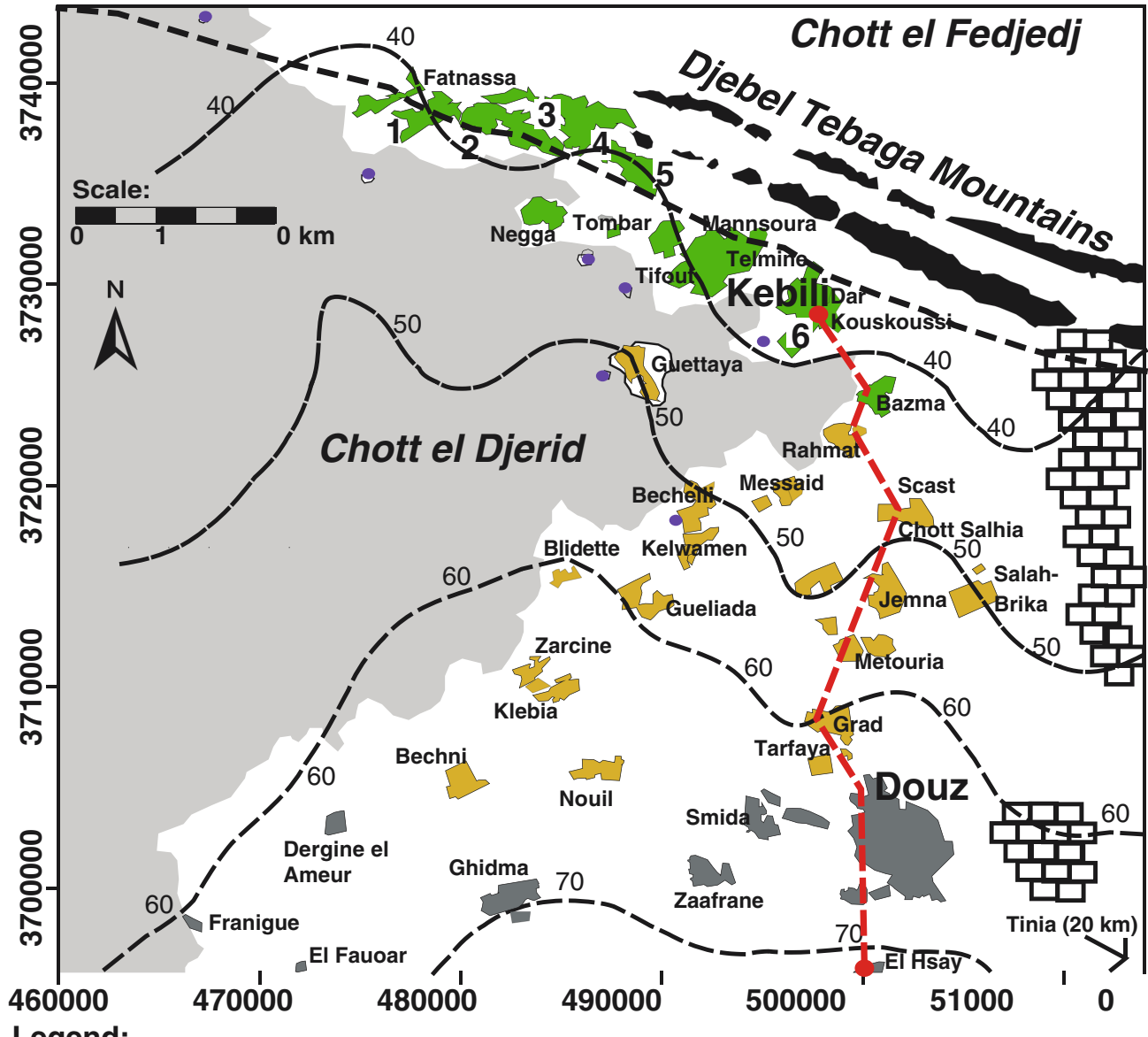

Legend:

$$
\begin{aligned}
& \text { ( } 50 \text { Piezometric } \\
& \text { ' } \checkmark \text { ' Kebili-Tozeur } \\
& \text { Fault } \\
& \text { - Spring mounds } \\
& \checkmark \cdot \text { Chemical }
\end{aligned}
$$

Abbreviated oases:

1 Taouergha

4 El Glea

2 Mennchia and Ziret Louhichi
5 Oued Zira

3 Bou Abdallah

6 Ksar Tabeul 
Fig. 3 Development of CT water abstraction (q) in the Nefzawa oases region. Note the pronounced growth of unofficial (illicit) pumping. The leveling off in the case of the illicit wells is not observed but represents a lack of data after 1996 and is certainly a conservative estimate of the actual pumped quantity from illicit wells

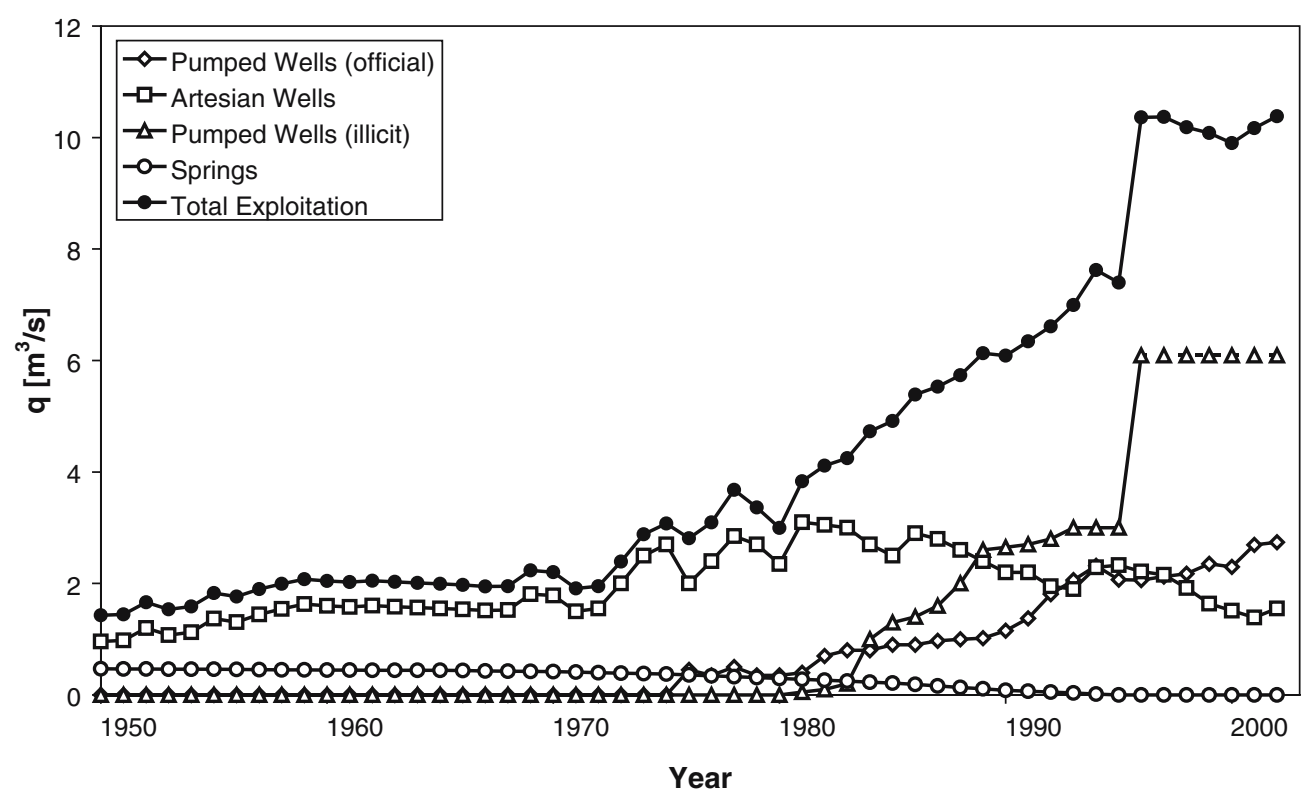

$6 \mathrm{~m}^{3} / \mathrm{s}$ in 2002. Piezometric levels in the CT aquifer in the region have fallen at an average rate of $1 \mathrm{~m} / \mathrm{a}$ over the last 30 years (Mamou and Hlaimi 1999b).

With increasing abstraction activity, a gradual salinization of soil and groundwater resources was observed, which threatens irrigated agriculture in the south of Tunisia. In some places such as the El Hsay oasis in the southern Nefzawa oases (Fig. 2), the yields and quality of the dates are diminishing at an alarming rate due to the combined effects of the application of enriched irrigation water and soil salinization.

The situation is likely to worsen in the future. In the whole of the CT basin (its northeastern part is shown in Fig. 1), planned groundwater withdrawals will reach $89.7 \mathrm{~m}^{3} / \mathrm{s}$ by 2050 compared to $42.7 \mathrm{~m}^{3} / \mathrm{s}$ in the year 2000 (Besbes et al. 2003; OSS 2003). Over the same time period, an increase of $1.1 \mathrm{~m}^{3} / \mathrm{s}$ of abstraction is projected in the Nefzawa oases region. Although this is a marginal increase locally, the regional CT piezometric levels are influenced by the basin-wide, transboundary groundwaterabstraction activity in the aquifer leading in combination to a considerable decline of piezometric heads.

In contrast to the mechanisms of soil salinization, the sources of groundwater salinization in the Nefzawa oases region have not yet been identified and remain ambiguous. The salinization phenomena in the region are complex. Several possible causes for salinization exist: (1) brine intrusion from the Chott el Djerid, i.e. a vast nearby salt lake; (2) salt-water upconing from saline underlying aquifers and (3) seepage of agricultural drainage water.

This report attempts to find an explanation for the deterioration in CT groundwater quality. The relevance of processes is discussed with regard to their present and future impact on CT groundwater. Data from the Tunisian agencies responsible for the management of surface water and groundwater resources-i.e. Commissariats Région- aux au Développement Agricole (CRDA), Kebili and Direction Générale des Ressources en Eau (DGRE) in Tunis - have been collected and analyzed. During numerous field trips in 2002, complementary water samples were taken and hydrochemical as well as isotopic analyses carried out.

In the remainder of the report, the geology of the Nefzawa area is presented and different potential causes of groundwater quality deterioration are highlighted and discussed. The results from tracer analyses are presented and conclusions drawn with regard to the origins of the salinization. Finally, a numerical groundwater flow and contaminant transport model of the area is presented. The model helps to assess different future water allocation strategies with regard to their potential impact on drawdown and water quality. Furthermore, it will help to sensitize local authorities with regard to the formation of future allocation strategies and their impact on the salinization of the $\mathrm{CT}$ groundwater resource.

\section{Hydrogeology and hydrochemistry of the Nefzawa oases region}

\section{Hydrogeology}

Among the different aquifer systems that exist in the Nefzawa oases region, the CT and CI formations are the two major ones with regard to extent and their relevance for yield. Phreatic aquifers of variable quantity and quality are only used for backup supply in times of extreme water shortage. The aquifer of the CT extends over an area of approximately $670,000 \mathrm{~km}^{2}$ in the northern Sahara. The term Complexe Terminal describes a multi-layer aquifer which consists of the Upper Cretaceous formations in the northern Saharan basin, i.e. the Upper and Lower Senonian and sandy formations of the Eocene and the 
Fig. 4 Generalized conceptual geological model of the Nefzawa oases region (not scaled). The homogeneous sequence of rock layers is interrupted by the Kébili-Tozeur Fault (based on (Mamou 1990; UNESCO 1972)

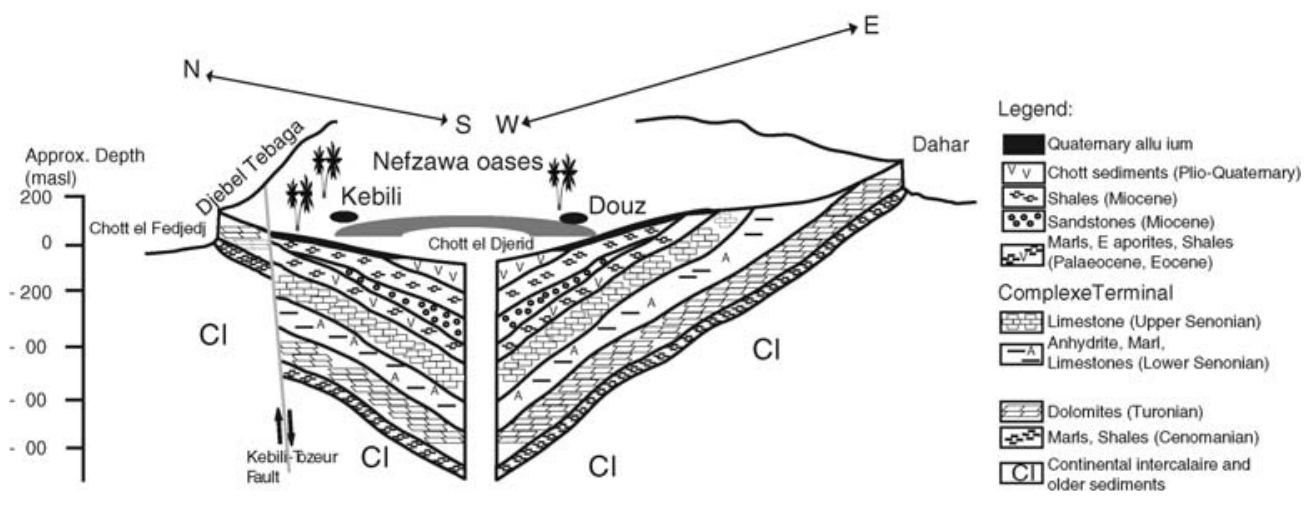

Mio-Pliocene (see Fig. 4). Evidence of hydraulic continuity between the Cretaceous and the Tertiary formations can be found in the whole basin except in the area close to the Chott el Djerid. Over most of the Nefzawa oases region marls of the Paleocene and evaporitic sediments of the Eocene confine the CT.

In the Nefzawa oases region, the thickness of the CT varies between $100 \mathrm{~m}$ in the northeast and $400 \mathrm{~m}$ towards the southwest. The depth to the top ranges from 50 to $100 \mathrm{~m}$ generally increasing from east to west and towards the Chott el Djerid. The most recent cover consists of sands as well as shales of the Mio-Pliocene and the Quaternary alluvium. In the Nefzawa region, the Senonian limestones are primarily exploited due to their high yield (Mamou and Hlaimi 1999b; OSS 2003; UNESCO 1972).

Towards the east, these limestones are cropping out (see Fig. 2). The exposure to weathering has left them highly karstified. In the riverbeds, the CT gets recharged by direct infiltration through floods descending from the Djebel Tebaga and Dahar mountain ranges located to the north and east of the Nefzawa region. In the central basin, water ages dated by radiocarbon (C14) indicate paleogroundwater of Pleistocene and early Holocene age $(28,000-5,000$ years), whereas younger water ages, at the fringes of the basin where CT formations outcrop, are an indication of modern recharge (Edmunds et al. 1997). However, present recharge is low due to the arid to hyperarid conditions within the catchment and depends mostly on infrequent storm events. The groundwater flow in the $\mathrm{CT}$ aquifer in the Nefzawa oases region is in general from the south and east towards the Chott el Djerid (see Fig. 2). For the study area, flow occurs mainly from the east and southeast towards the west and northwest respectively. CT groundwater has a total dissolved solids (TDS) content ranging between 1,000 to $2,000 \mathrm{mg} / \mathrm{l}$ with locally increased values of up to $7,000 \mathrm{mg} / \mathrm{l}$.

As shown in Fig. 4, the underlying Turonian dolomites constitute a separate aquifer over large parts of the Nefzawa oases region. The mostly impermeable lagoonal Lower Senonian deposits seal the base of the CT. Towards the east in the Dahar mountain range, the Turonian dolomites are cropping out. Along the Kebili-Tozeur fault the Turonian dolomites form part of the $\mathrm{CT}$ where they contain freshwater. In contrast, the Turonian aquifer is of little interest with regard to exploitation in the central and southern part of the Nefzawa region due to high salinity with a TDS content of up to $7,000 \mathrm{mg} / \mathrm{l}$.

The CI is defined as the set of sedimentary layers that comprise mainly continental sandstone-clay formations of the lower Cretaceous. Associated with it are postPaleozoic and ante-Cenomanian marine or lagoon sediments. It is one of the largest groundwater systems in the world. In total, it covers an area of about $1,100,000 \mathrm{~km}^{2}$ in the northern Sahara sedimentary basin. It can be found at depths of 800-2,500 $\mathrm{m}$ with a thickness of around 300$1,200 \mathrm{~m}$. Most of the wells tapping the CI show strong artesian conditions. Similar to the CT, the groundwater of the CI is mainly paleogroundwater which dates back to the Pleistocene and early Holocene (UNESCO 1972). Recent recharge is observed at the periphery of the Sahara basin (Edmunds et al. 1997). The water is geothermal with temperatures between 60 and $70^{\circ} \mathrm{C}$. The $\mathrm{CI}$, as the CT, is a multilayer aquifer. The CI includes the different aquifers between the base of the Triassic and the top of the Albian (UNESCO 1972). Its confining unit is clearly defined as the Cenomanian shales, which separate the CI from the Turonian. In the Nefzawa region, the main aquifers are situated in the Lower Cretaceous from the Barremian to the Albian and their base is defined by the shales of the Upper Jurassic (Malm). The general flow of CI groundwater is from the southeast towards the northwest. CI groundwater quality in the Nefzawa oases region is mediocre with TDS ranging from 2,000 to $4,000 \mathrm{mg} / \mathrm{l}$.

The phreatic aquifers are found in the Mio-Plio-Quaternary sediments and the alluvial fillings of the wadis, i.e. the beds of ephemeral rivers. With regard to exploitation, they are only of secondary importance because their water is usually highly salinized with $2,000-10,000 \mathrm{mg} / \mathrm{l}$ TDS (ElFahem 2003; Mamou and Hlaimi 1999b). In the Presquîle de Kebili (PIK), which corresponds to the northwestern part of the Nefzawa region (see Fig. 2), located between the Djebel Tebaga and the Chott el Djerid, TDS observations in the $1960 \mathrm{~s}$ showed salinity to range from 5,000 to $12,000 \mathrm{mg} / \mathrm{l}$ (Pouget 1966). The phreatic aquifers are recharged by vertical percolation from the confined CT and by infiltration of excess irrigation water as well as water from flood events that descend in the wadis from the surrounding mountains to the Chott el Djerid. Generally, 
their piezometric level is elevated in the irrigated oases areas and diminishes with increasing distance from them. Measurements of the water table show a depth below ground level increasing from $1 \mathrm{~m}$ in the PIK to $5 \mathrm{~m}$ in Douz within the irrigated perimeter. Outside the oases, lower water tables have been measured ranging from $9 \mathrm{~m}$ in the PIK to $14 \mathrm{~m}$ in Douz (Direction Générale des Resources en Eau 2000). The flow direction of the phreatic groundwater is generally towards the Chott el Djerid.

In times of shortage during the summer months, water from the phreatic aquifers is used for irrigation to complement the official water allotment. Due to the mediocre water quality, these waters have to be diluted with CT water to lower the TDS concentration. In the year 2000 , exploitation was approximately $0.05 \mathrm{~m}^{3} / \mathrm{s}$ of which more than $70 \%$ was utilized in the southern Nefzawa oases region (Douz and El Hsay oases; Kriaa 2003).

The Chott el Djerid covers an area of approximately $5,400 \mathrm{~km}^{2}$. It is a playa system in a subsidence basin located between the southern flank of the Djebel Tebaga mountain range and the northern part of the Saharan platform. Under natural conditions, the Chott was the discharge area for water from the $\mathrm{CT}$ and the phreatic aquifers. Groundwater within the Chott is highly salinized, often exceeding 100,000 mg/l of dissolved salts (Gueddari 1980). The hydrogeology of the Chott aquifer is not well understood and no wells or piezometers exist within it. Large parts of the Chott are covered by silty sediments and crusts formed by salts. The sedimentation of the Chott el Djerid has been evaporitic and lacustrine since the late Pleistocene. Geological log samples taken in different areas in the Chott show layers of clays and salty materials (gypsum) to a depth of around $60 \mathrm{~m}$ which is the maximum thickness of the Quaternary Chott sediments. Between 60 and $125 \mathrm{~m}$ below ground surface (bgs), there are sandy sediments from the Mio-Pliocene with clayey and salty intercalated layers (Meckelein 1977). Bedded marly sandstones or red shales are found at the bottom in the center of the Chott up to a depth of about $900 \mathrm{~m}$. The water table is high, ranging from 0.2 to $0.5 \mathrm{~m}$ below the surface. Winter flood events can cause standing water in some areas of the Chott.

An interesting but still not clearly understood natural feature in this context is the occurrence of spring mounds on the fringes of the Chott el Djerid in the Nefzawa oases region. In the past, CT water evaporated in these spring mounds after having risen through preferential flow paths from the CT towards the Quaternary surface (Meckelein 1977). The lowering of the hydraulic heads of the CT in recent years has caused a complete drying up of the springs.

\section{Complexe Terminal hydrochemistry}

Hydrochemical investigations in the Nefzawa oases region started in the late 1950s. However, systematic and continuous observations are only available from 1980 onwards. At this time, CT water of the PIK oases were elevated in TDS $(2,000-3,500 \mathrm{mg} / \mathrm{l})$ when compared to the rest of the Nefzawa oases $(1,000-2,000 \mathrm{mg} / \mathrm{l}$ on average; El-Fahem 2003). During the last 20 years, an increase in TDS of 1,000-2,000 mg/l was observed in the PIK, e.g. Ras el Ain, Bou Abdallah and Telmine oases (El-Fahem 2003). In the southerly Douz region, including the El Hsay oasis, the TDS increased by more than 3,000$4,000 \mathrm{mg} / \mathrm{l}$ over the same period (El-Fahem 2003). As a consequence, some of the pumped water is no longer suitable for irrigation. In contrast, oases situated in the central region as well as next to the Chott el Djerid, e.g. Negga, Ghidma and Guettaya, do not show any deterioration of water quality (see Fig. 5).

The chemical N-S cross-sections through the study region depict the situation in 2002 (see Fig. 6, the geographic location is shown in Fig. 2). The sections show that the salinization chemistry is changing towards the south. Here, concentrations of sodium and chloride are relatively enriched. This could be an indication of evaporation processes that influence the local groundwater chemistry. However, it is noteworthy that the change in salinity is not homogeneously distributed within the affected regions, neither temporally nor spatially. Even inside the same oasis such as for example Ras el Ain, CT boreholes located in close proximity to each other show different behavior.

As mentioned previously, three different salinity sources are the likely causes for the deteriorating quality of CT water in the Nefzawa oases region. These sources and related salinization mechanisms are shown in Fig. 7 and discussed below.The Chott el Djerid contains very saline groundwater within its Tertiary and Quaternary sediments. TDS values range from 10,000 up to 350,000 mg/l (El-Fahem 2003; Gueddari 1980; Kbir-

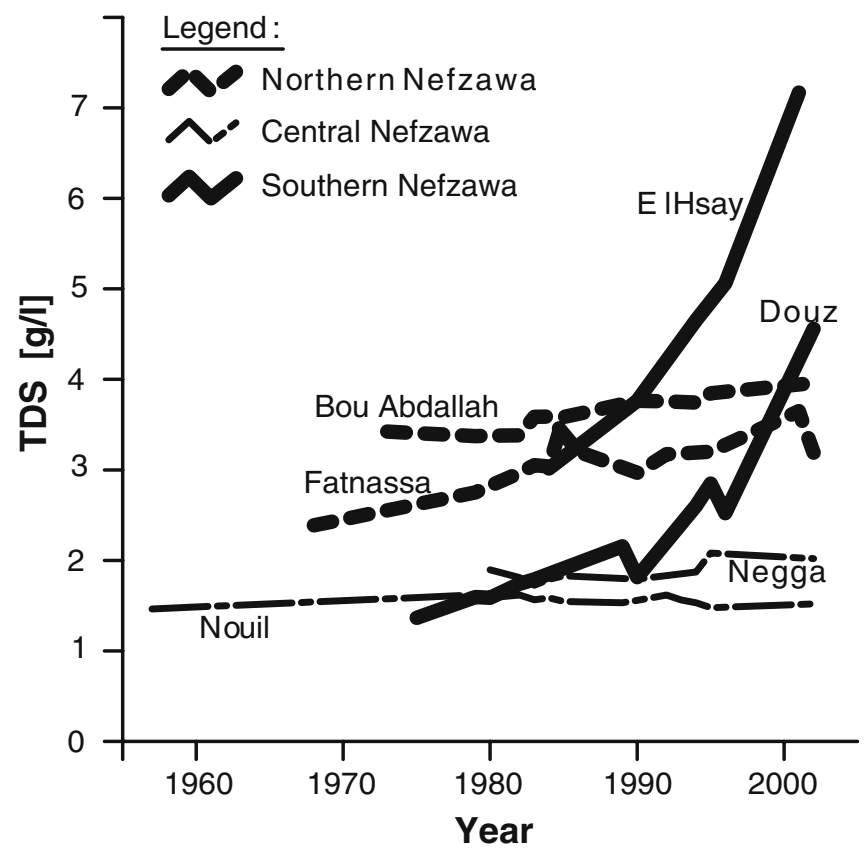

Fig. 5 Exemplary total dissolved solids (TDS) development in the Nefzawa oases showing the different regional salinization trends of CT water 
Fig. 6 Chemical cross-sections through the study area. $\mathbf{a}$ cations and $\mathbf{b}$ anions. Quality deterioration is observed in the PIK and Kebili region (Dar Kouskoussi and Ksar Tabeul 2) as well as in the southern Nefzawa (see Fig. 2 for locations). Groundwater samples were taken in the field in 2002. Boreholes marked by bis denote replacement pumping infrastructure of original boreholes that are no longer in operation. Units in $\mathrm{mg} / \mathrm{l}$
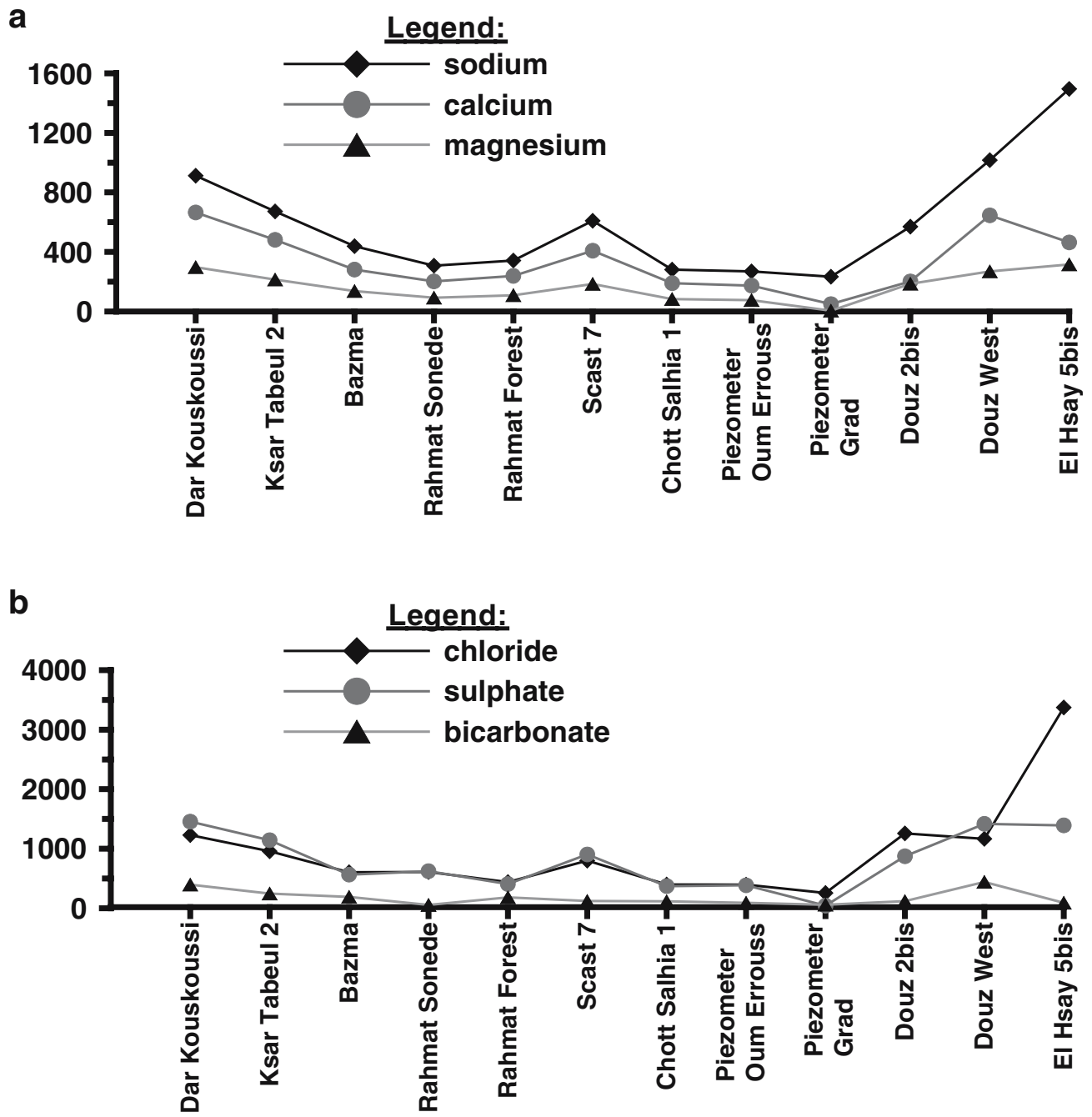

Ariguib et al. 2001).Under natural conditions, the elevated $\mathrm{CT}$ head relative to the shallow groundwater piezometry in the Chott prevented any significant downward percolation of brine. Progressive groundwater mining lowered the CT head leading to an inversion of the hydraulic gradient in the CT. Figure 7 shows how the infiltration of Chott water into the $\mathrm{CT}$ may be caused by such a gradient inversion. Piezometric levels in the CT prior and during exploitation are shown in a schematic way. It is conceivable that Chott water infiltrates into the $\mathrm{CT}$ with the progression of the gradient inversion. In this case, infiltrating water has to pass the semipermeable aquitard of the Paleocene marls and evaporites. Although these clays cover most of the Cretaceous in the Nefzawa oases region, their thickness varies. After sedimentation in the late Pleistocene, these clays were exposed to erosion on the surface. Hence, percolation through these strata, further accentuated by density driven flow of brine from the Chott el Djerid, might be possible locally.

Turonian and CI water are a second potential source of salinity in the Nefzawa oases region. Both show increased salinity in this area. In the Turonian aquifer, measured TDS values range from 2,500 to $3,500 \mathrm{mg} / 1$ in the PIK to
$7,000 \mathrm{mg} / \mathrm{l}$ in the southeastern part of the Nefzawa region (El-Fahem 2003). Similarly, TDS in the CI increase from 2,500 to 3,500 mg/l in the PIK to 4,000 mg/l in Douz (ElFahem 2003). It is likely that salinization of the CT occurs where continuity between these aquifers exists. The higher pressure heads of the Turonian and CI allow their water to percolate upward. With a lowered piezometric level of the CT due to groundwater mining and the level in the Turonian remaining unchanged, this upwelling might be increased and could lead to a density layering in the basal zone of the CT formation (see Fig. 7). Under these circumstances, pumping possibly triggers upconing which would explain a quality deterioration of the pumped $\mathrm{CT}$ water.

Finally, agricultural drainage water with an increased TDS collects in terrain depressions, so-called sebkhas, where it gets enriched due to strong evaporation. The TDS of drainage water varies from $8,000 \mathrm{mg} / \mathrm{l}$ in winter to $25,000 \mathrm{mg} / 1$ in summer. In autumn 2001 , the measured TDS in the sebkha of El Hsay reached 100,000 mg/l (ElFahem 2003). Especially in the summer months, drainage waters do not get flushed out to the more distant Chott el Djerid due to greatly reduced flow. These waters then 
Fig. 7 Conceptualization of the three different salinization processes: a infiltration of brine from Chott; b upconing of water from the CI/Turonian aquifer; c salinization by agricultural drainage water. Representative salinity is given in total dissolved solids (TDS; El-Fahem 2003)

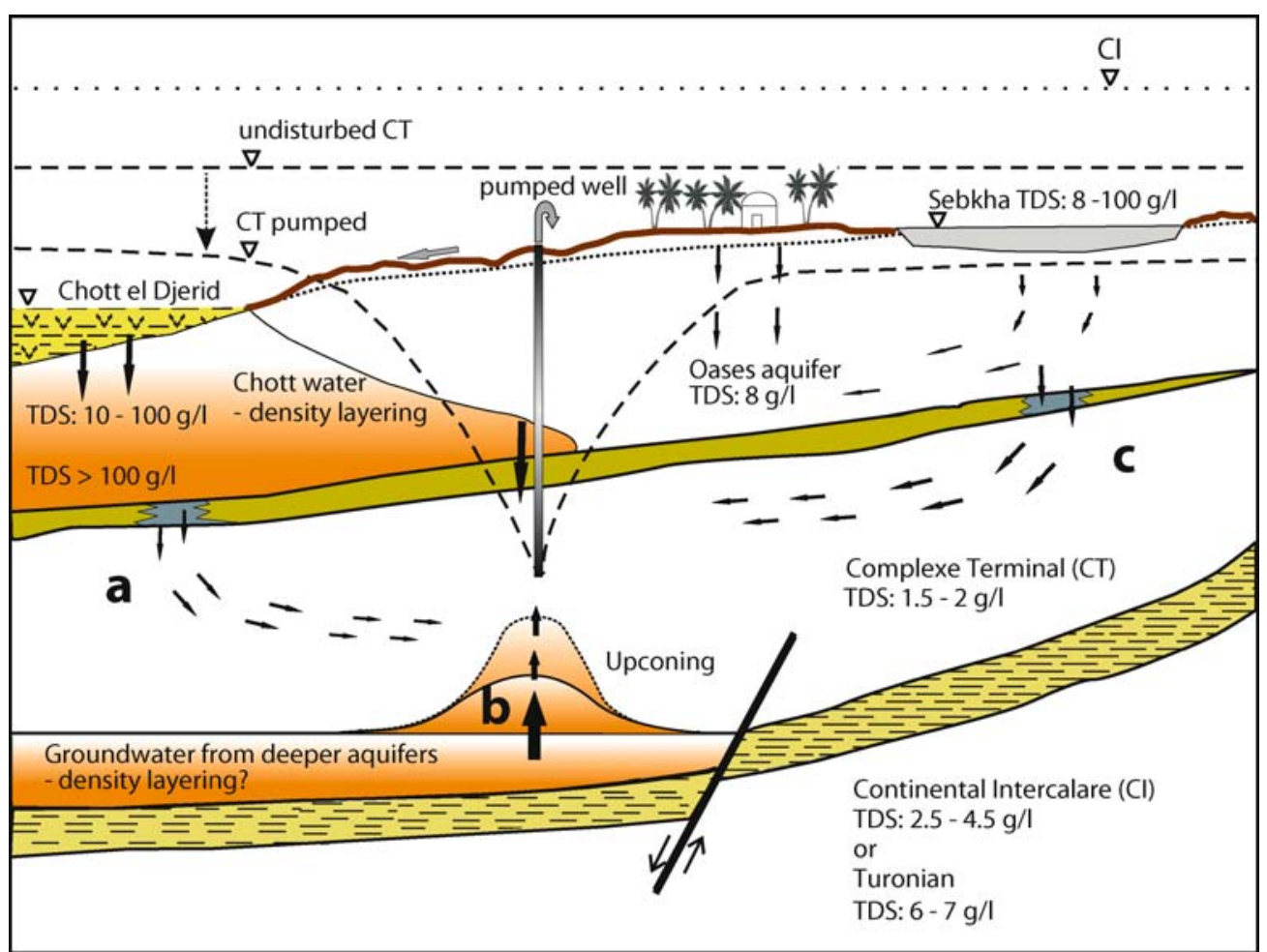

Legend:

$\underline{\boldsymbol{\nabla}}$ _ _ Piezometric level of the $C T$

Confining clays of the Mio-Pliocene

Evaporites of the Chott El Djerid
ग. . . Piezometric level of the $\mathrm{Cl}$

Confinement of the $\mathrm{Cl}$ (Turonian, lagoonal Senonian)

Zone of structural weakness or change of rock facies
7......... Piezometric level of the oasis aquifer

Faultline

| Flow of water collect in the sebkhas within close proximity of the oases and infiltrate to the underlying shallow aquifer (Direction Générale des Resources en Eau 2000). The confining layers of the Mio-Pliocene are not continuous (see Fig. 7). They might be thinning and forming lenses thus containing preferential infiltration pathways. Locally, in areas of high exploitation where a lowering of the CT head below the head of the oases aquifer is observed, either oases drainage water or highly salinized water from the sebkhas might infiltrate into the CT.

\section{Determination of the origins of salinization}

To obtain an understanding of the complex salinization phenomena observed in the Nefzawa oases, data on chemistry, temperature and isotopes available at the CRDA, Kebili were obtained for the period from 1957 to 2000. This data set was complemented by sampling groundwater and temperature at 53 sites including deep wells in the CT and CI, shallow wells, drains and sebkhas in 2002. Subsequently, the chemistry of and the radio- isotopes $\left({ }^{2} \mathrm{H},{ }^{3} \mathrm{H},{ }^{18} \mathrm{O}\right)$ within the samples were analyzed. All sampling was coordinated with local representatives. Data are provided in Table 1.

Firstly, considering the correlation between the pointwise CT salinity increase and pumping, piezometry as well as structural properties were investigated. No significant correlation was found between salinity increases and pumping amounts or decline of hydraulic heads in the CT. However, a strong relationship exists between increasing TDS and depth to the top of the CT. The latter is generally coincident with the top of the screen in most of the boreholes. Boreholes tapping the CT near to the surface show a pronounced increase in the TDS whereas deeper CT boreholes do not show any sign of deterioration in the pumped water quality (see Fig. 8). The phenomenon is visible in the northern (PIK, Kebili) and southern Nefzawa region (Douz, El Hsay). This result indicates possible salinization from the third source, i.e. from the phreatic aquifer where the shielding of the CT by its confining unit is less pronounced.

In order to further substantiate this finding, bromide/ chloride and sulphate/chloride ratios were plotted against 


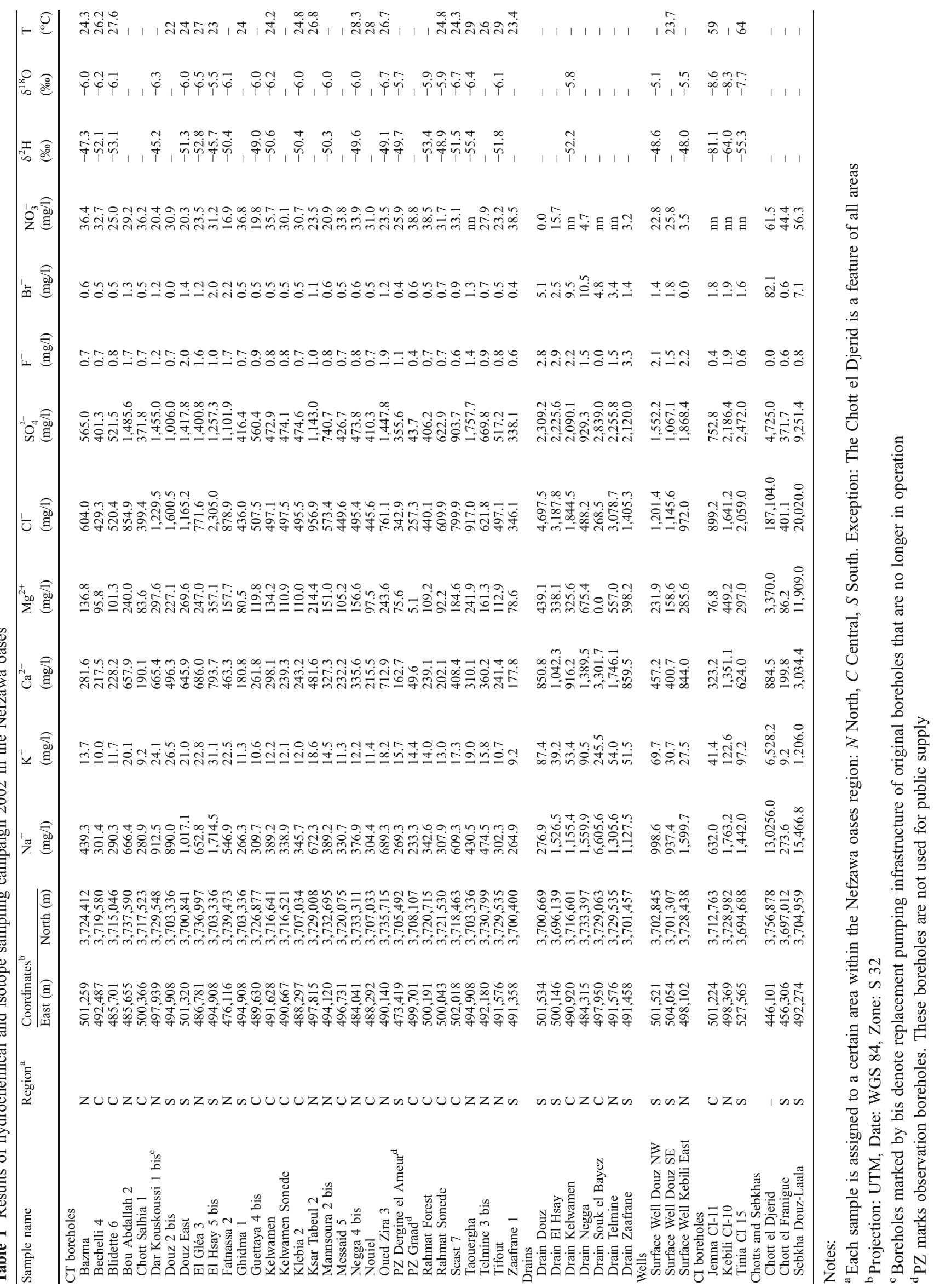


Fig. 8 CT salinity development between 1980 and 1997, i.e. $\triangle \mathrm{TDS}=\mathrm{TDS}(1997)-\mathrm{TDS}$ (1980), at different locations in the Nefzawa oases region in relation to depth to the top of the CT (Kriaa 2003). CT water temperatures are shown for selected oases (see also map in Fig.2 for the locations). An average geothermal gradient of $5.5^{\circ} \mathrm{C} / 29 \mathrm{~m}=20^{\circ} \mathrm{C} / \mathrm{km}$ can be calculated. Note that Negga 2 bis is located several kilometers south of the KebiliTozeur fault in the PIK and is not affected by CI water upwelling

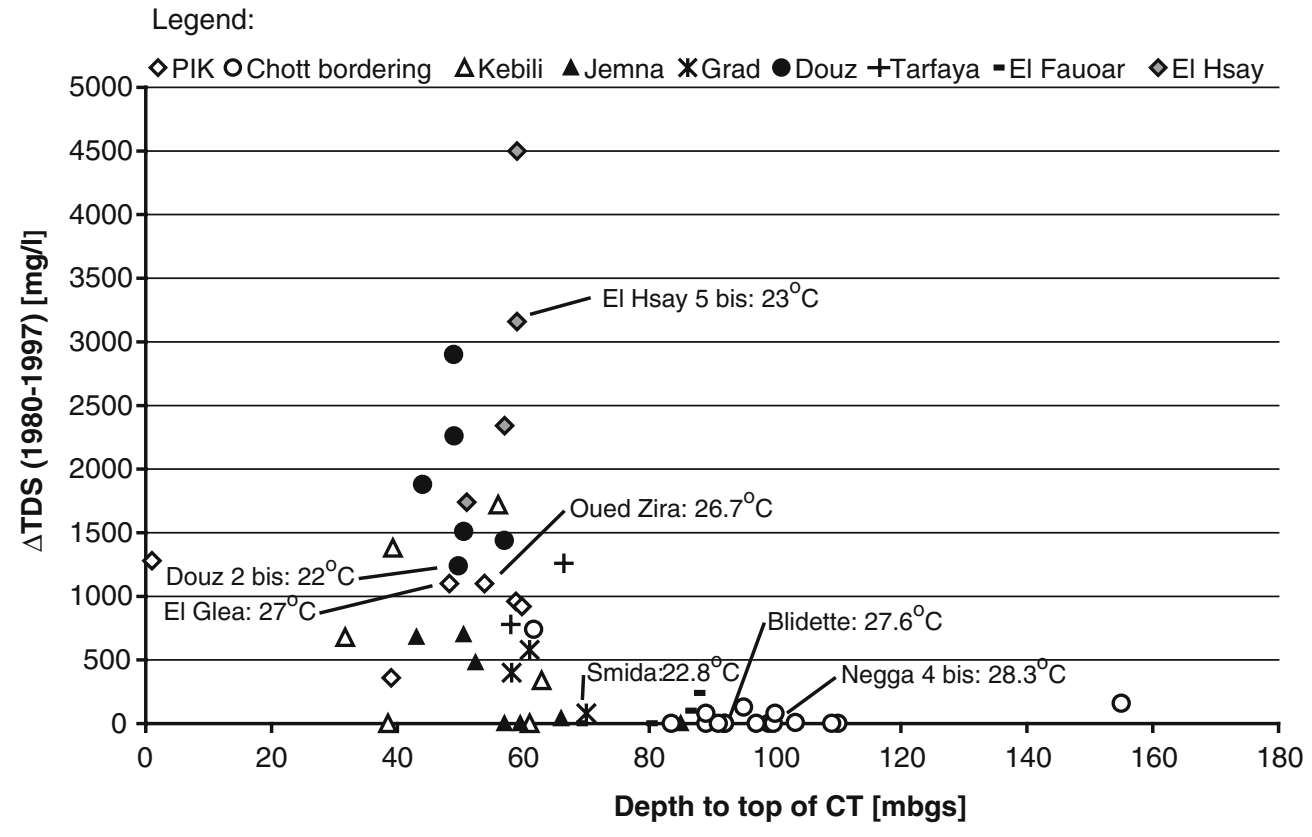

each other. Chloride and bromide are the two most during the mixing of different waters, and is usually much conservative constituents in water, i.e. they are little more conservative than dissolved cations (Whittemore affected by chemical reactions such as mineral precipitation 1984, 1988). The results are shown in Fig. 9. CT samples or adsorption. Similarly, sulphate is generally conservative from Douz and El Hsay Oases show similar ion ratios to

Fig. 9 The plot shows $\mathrm{Br}^{-} /$ $\mathrm{Cl}^{-}$vs. $\mathrm{SO}_{4}^{2-} / \mathrm{Cl}^{-}$ion ratios. The dashed lines separate regional ion ratio clusters. (PIK Presquîle de Kebili, $N+C$ northern and central Nefzawa region, $S$ southern Nefzawa). The two CT wells/boreholes, Douz 2 bis and El Hsay 5 bis, show similarities in their ion ratios and with the ion ratio of the corresponding surface water samples from nearby locations. Although of different ionic characteristics compared to the other samples in the southern Nefzawa region, Douz West and the Surface Well Douz NW are chemically related. $P Z$ means piezometer

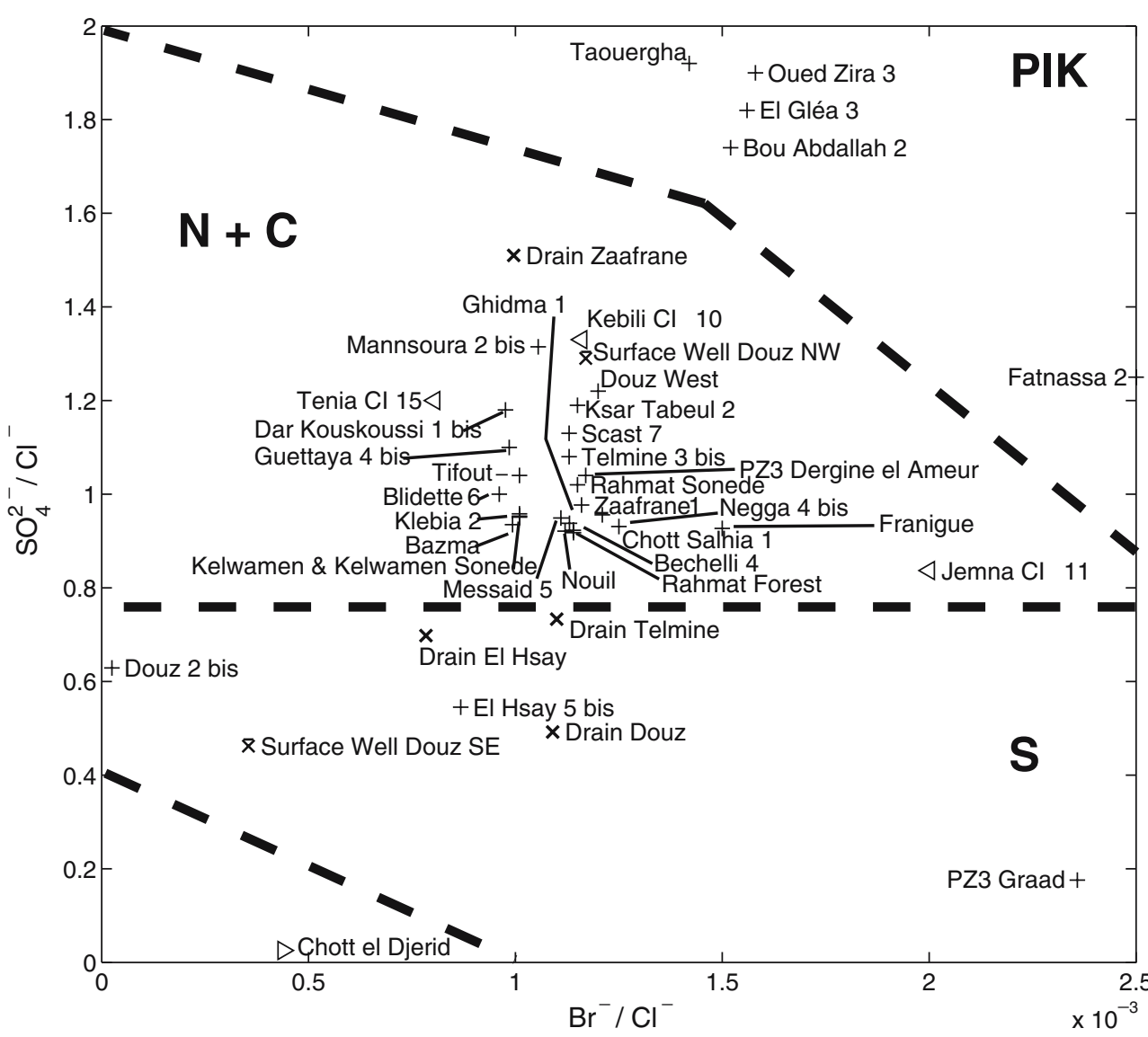

Legend: $+\mathrm{CT}$ boreholes $\times$ Drains $\triangleleft \mathrm{Cl}$ boreholes $\triangleright$ Chott $\times$ Surface Wells 
those in the water from drains and surface wells located in close proximity, i.e. Douz 2 bis/Surface Well Douz SE as well as El Hsay 5 bis and Drain El Hsay and finally Douz Ouest/Surface Well Douz NW (see Fig. 9). Boreholes marked by "bis" denote replacement pumping infrastructure of original boreholes that are no longer in operation.

A downward percolation of TDS enriched shallow groundwater can only occur if the piezometric head of the Oases Aquifer is locally higher than the CT head. By 1996, artesian conditions within the CT around Douz and El Hsay had retreated up to $10 \mathrm{~km}$ west of these oases in the direction of the Chott el Djerid. In 2002, CT piezometric levels were up to $20 \mathrm{~m}$ below ground level (bgl). Hence, conditions conducive for direct infiltration prevail in the southern Nefzawa region. In contrast, groundwater samples from CT boreholes in the PIK and northern Nefzawa region show no similarity to surface water samples taken locally, i.e. Drain Telmine. The hypothesis of surface water contamination cannot be maintained in these areas. Rather, the influence of geothermal CI water in the PIK seems evident from the observed temperature anomaly of the $\mathrm{CT}$ groundwater. The average CT water temperature in the central and southern CT in the Nefzawa oases region is around $24^{\circ} \mathrm{C}$. In the northern Nefzawa and the PIK, the average temperature increases to approximately $27^{\circ} \mathrm{C}$. Figure 8 shows CT water temperatures for selected oases. The temperature of groundwater in boreholes not affected by contamination as well as from the oases of El Hsay and Douz 2 bis in the southern Nefzawa region follow nicely the regional geothermal gradient of about $20^{\circ} \mathrm{C} / \mathrm{km}$ (Ben Dhia and Bouri 1995). In contrast, the temperature anomalies of the boreholes at El Glea $\left(27^{\circ} \mathrm{C}\right)$ and Oued Zira $\left(26.7^{\circ} \mathrm{C}\right)$ located in the PIK are clearly visible. These anomalies cannot be explained by borehole screen depth alone. The mixing of CT groundwater with water from the CI is a likely source of salinization (see also Mamou 1990).

Isotopic analysis further supports the above results. Stable isotope samples from the CI obtained in 2002 are grouped together with the samples from the Etude des Resources en Eau du Sahara Septentrional (ERESS) study (UNESCO
1972) along with the local meteoric water line (LMWL) in Fig. 10. The LMWL was produced based on rainfall isotope data from the rainfall sampling stations at Sfax and Nefta in Tunisia. Data was obtained from the Global Network of Isotopes in Precipitation (GNIP) database (IAEA 2001).

In contrast, CT samples mostly cluster below the LMWL and are shifted to the right. Their isotopic compositions follow a characteristic evaporation line which was interpolated from the CT data set. The CT evaporation line crosses the LMWL at $-7.5 \% \delta^{18} \mathrm{O}$ and $-55.1 \% \delta^{2} \mathrm{H}$. This intersection is in the vicinity of the CI samples. Original $\mathrm{CT}$ and CI waters were formed by precipitation during Pluvial ages and are of the same origin. The shifting of CT samples along the evaporation line shows that the $\mathrm{CT}$ receives younger recharge waters that have been subject to evaporation.

Apart from direct infiltration of local drainage water from the phreatic aquifer, a more distant source of saline phreatic water has to be considered as well. In their report, (Mamou and Hlaimi 1999a) present stable isotope measurements of phreatic water samples taken to the south and the east of the study area (see Fig. 10). The samples show a strong evaporative nature, being aligned along the same evaporation line as the CT samples from the southern Nefzawa region. The CT is partly outcropping and partly covered by dunes 30 to $50 \mathrm{~km}$ to the south and east of the Nefzawa oases region. In this region, enriched phreatic water can easily infiltrate into the CT. Since the general groundwater flow direction is southeast to northwest towards the Chott el Djerid, it is evident that the CT groundwater in the south and east of the Nefzawa region is enriched in isotopes due to mixing with recent water subject to strong evaporation. Recent water has not yet replaced the paleowater in the $\mathrm{CT}$ and the present isotopic pattern of the CT waters in this area marks the transition in climatic conditions during the Holocene. Given time, all paleowater will eventually be replaced by modern water.

In contrast, the relative shift of stable isotope values for the northern Nefzawa towards the LMWL is most likely caused by $\mathrm{CI}$ groundwater upwelling. Direct recharge alone, through preferential pathways in the fractured
Fig. 10 Relationship of $\delta^{2} \mathrm{H}$ and $\delta^{18} \mathrm{O}$ for samples from $C T$ and $C I$ taken during the field campaign 2002 (see Table1). CT samples are from different areas. The evaporation line was interpolated from all available isotope data of the area

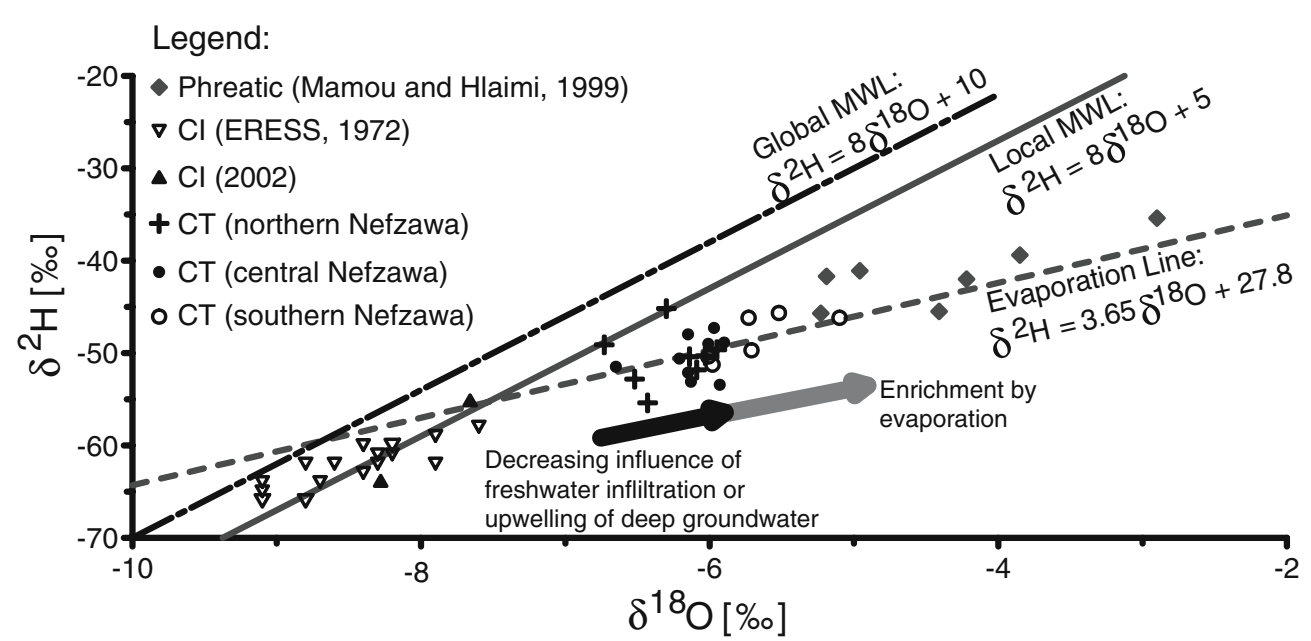


limestones and dolomites on the southern flank of the Djebel Tebaga, could not explain the observed temperature anomaly.

No correlation between distance of borehole from the Chott el Djerid and TDS development has been found (Kriaa 2003). Oases adjacent to the Chott el Djerid such as Negga, Gueliada and Ghidma do not show any signs of deterioration in $\mathrm{CT}$ water quality. Any present day influence of brine from the Chott is not visible and its relevance as a source of salinization is refuted. However, this may not hold true for the future when a regional scale gradient inversion will occur. The relevance of this salinization source with regard to planned aquifer exploitation is discussed below.

\section{Groundwater modeling approach}

\section{Flow model}

In order to assess the future impact of pumping on the CT aquifer in the Nefzawa oases region over the next 50 years, a quasi three-dimensional finite-difference flow model was developed using MODFLOW-2000, a modular finitedifference groundwater model code (Harbaugh et al. 2000). For model pre- and post-processing, Processing MODFLOW was utilized (Chiang and Kinzelbach 2001). The development and calibration of the model are based on previous work by ARMINES and Ecole Nationale
d'Ingénieurs de Tunis (ENIT 1984); Observatoire du Sahara et du Sahel (OSS 2003); United Nations Educational Scientific and Cultural Organization (UNESCO 1972) and are described in detail in (Kriaa 2003).

The study area covers approximately $5,500 \mathrm{~km}^{2}$ and was horizontally discretized into square cells of $780 \mathrm{~m}$ side length (see Figs. 11 and 12). The northeastern boundary of the model follows the CT basin boundary. The other limits are artificially chosen with general head boundary conditions that represent the hydraulic connection to the greater CT basin. These time-variable thirdtype or Cauchy boundary conditions define the flux and head over the domain limit.

Vertically, the upper model layer corresponds to the phreatic aquifers which are laterally connected to the Chott aquifer. The upper layer geometry is shown in Fig. 11. Only very limited information about the phreatic aquifers, i.e. their extent and formation, is available (Mamou and Hlaimi 1999b). By combining the oases aquifers, the phreatic aquifers in the wadis as well as the Chott aquifer within one model layer, it is assumed that this aquifer extends over the whole study region within the Mio-Plio-Quaternary sediments. Evapotranspiration occurs from this layer only. Recharge from precipitation at the southern flank of Djebel Tebaga is modeled by prescribed inflow and an estimated $10^{5} \mathrm{~m}^{3} / \mathrm{a}$ is assumed (see Fig. 11). This corresponds to the value presented in (Mamou and Hlaimi 1999a).

Fig. 11 Nefzawa model extent and discretization of phreatic aquifer layers. $\mathrm{Or}$ ange cells: Chott el Djerid drain boundary conditions; Black cells: inactive cells; green cells: general head boundary cells indicating the agricultural drains; blue cells: recharge. Piezometric contour lines $(1-\mathrm{m}$ intervals from 18 $25 \mathrm{mas}$, 5 -m intervals from 25-70masl) are shown in meters above sea level for steady state conditions in 1950 (see also Fig. 1 for the location of the project area)

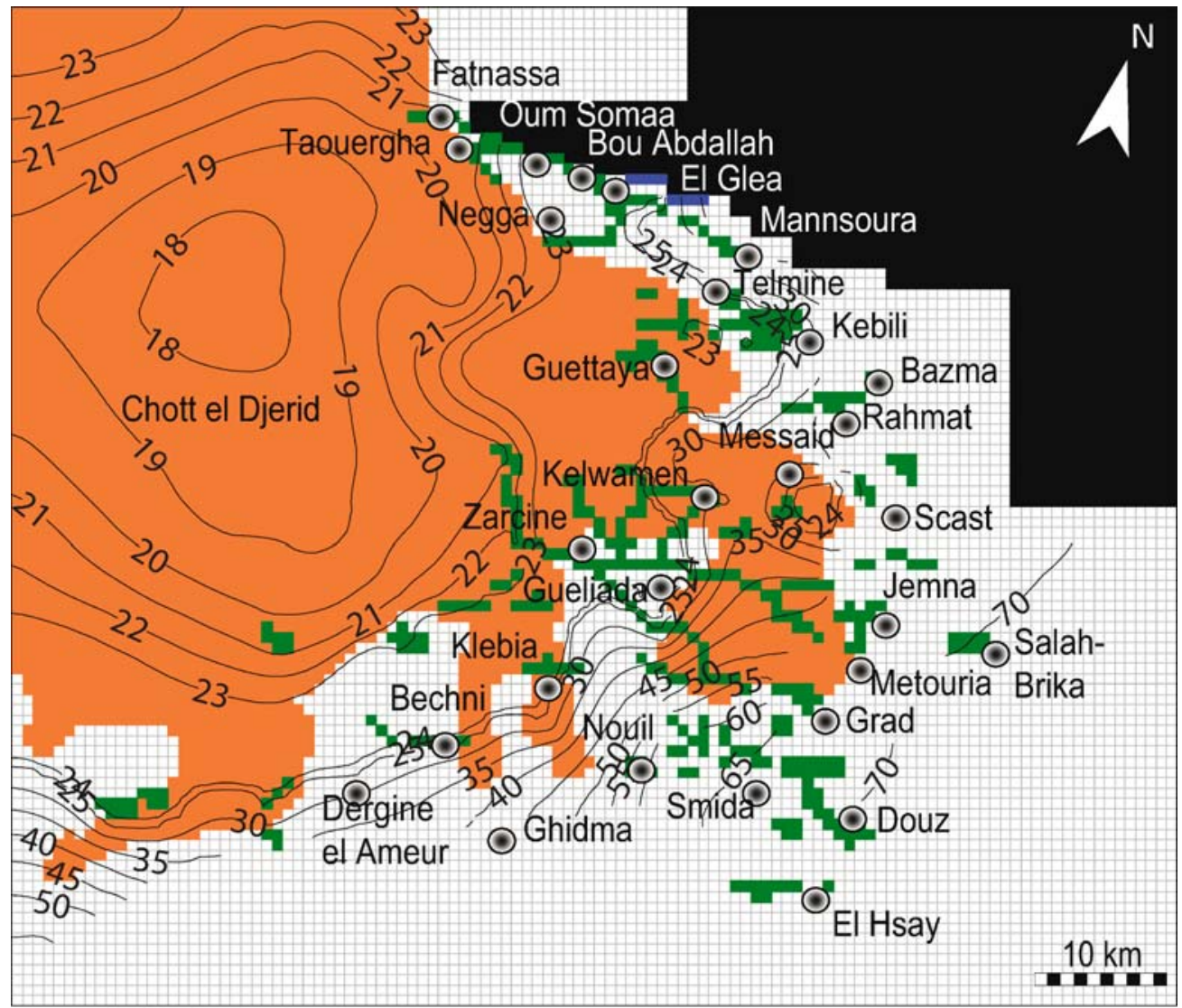

Legend: $\odot$ Oasis location 
Fig. 12 Nefzawa model extent and discretization of the CT. Black cells: inactive cells; red cells: pumping boreholes; green cells: general head boundary cells to account for the regional CT development; gray cells: drains at the southern flank of Djebel Tebaga (corresponds to the location of the natural springs). Piezometric contour lines (1-m intervals) in meters above sea level are shown for steady state conditions in 1950

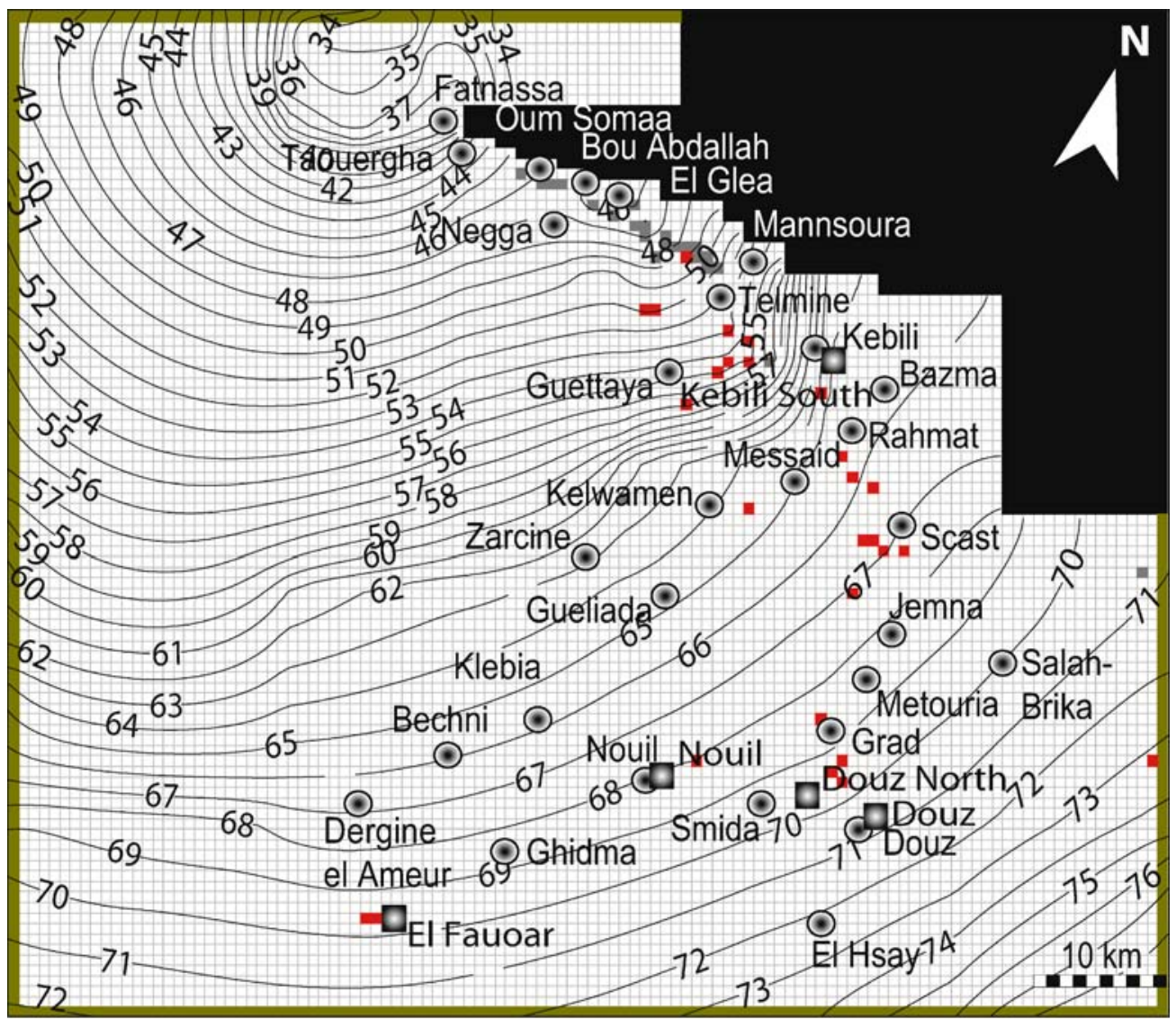

Legend: $\odot$ Oasis location $\mathbf{\square}$ Observation boreholes
Phreatic groundwater, generally following the terrain gradient, flows towards the Chott el Djerid where it gets removed by evaporation. On-farm drainage systems in the oases are represented by general head boundary conditions which allow exchange with the phreatic aquifer to be modeled. The location and geometry of the drain network were obtained by the superposition of a Landsat imageLandsat-7-Enhanced Thematic Mapper (ETM), 16 August 2000 - with the model grid. For steady state calculations, only the ancient oases have been accounted for, whereas the many new extensions of the irrigated perimeters from 1950 up to today are included in the transient model. Due to a lack of knowledge of hydraulic properties, i.e. hydraulic conductivities and storage coefficients, the confining clays, marls and evaporites between the two aquifers have not been modeled explicitly. Instead, the CT and Mio-PlioQuaternary sediments are connected by a leakage term.

Accordingly, the lower model layer then corresponds to the CT aquifer as depicted in Fig. 12. It incorporates the stratigraphic units of the upper and lower Senonian formations. Its geometry was interpolated from borehole $\log$ data. Springs are implemented as drains whose flow should be reproduced after model calibration (see Harbaugh et al. 2000) for more information on the Modflow-2000 Drain package). The connection to the Turonian aquifer is modeled by a general head boundary condition. Its representation helps to determine inflow via the Turonian to the CT in steady and transient state. The prescribed heads that connect this regional model to the greater CT basin vary in time in relation with the historical regional decline of the CT piezometric levels. The latter is observed in observation wells that are located both inside and outside of the study area.

The period taken as a reference for the steady state calibration of the model is 1950, during which the CT was considered to have been in a state of equilibrium on a basin wide level (OSS 2003; UNESCO 1972). Steadystate calibration consisted of reproducing the general piezometric maps for the phreatic and CT aquifers as well as the discharge rates at the Nefzawa springs as measured in 1950 (see Fig. 13). The time period from 1951 to 2000 was taken as the reference period for transient calibration. The reproduction of the drawdown trend as well as the temporal reproduction of the total measured spring discharge were taken as calibration criteria. The calibration parameters are horizontal transmissivities, storage coefficients and specific yield for the phreatic aquifer, leakage between the phreatic aquifer and the $\mathrm{CT}$ as well as between the CT and the Turonian aquifer and finally, the hydraulic resistances between the phreatic aquifer and the soil surface at the level of the springs and agricultural drains. The calibration process was manual. Note that the availability of discharge data makes the calibration exercise a well-posed problem. 

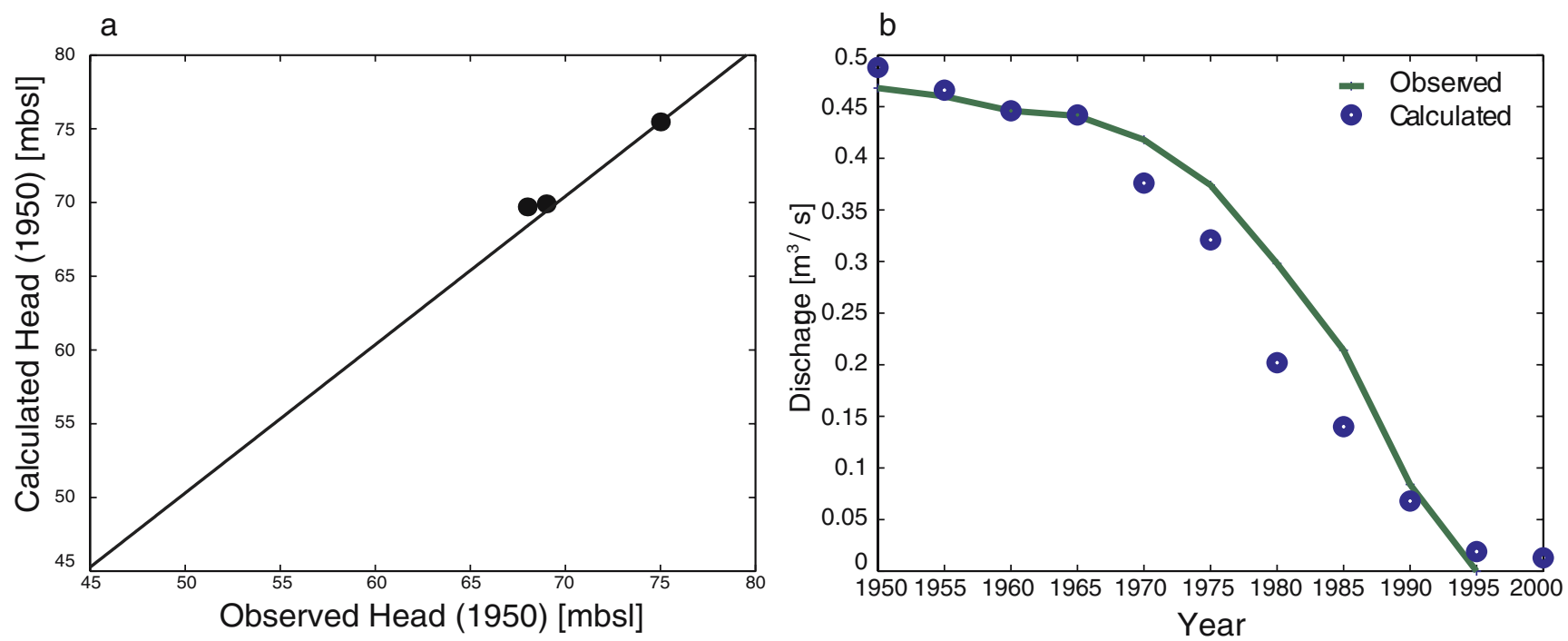

Fig. 13 a Scatter plot of steady-state head calibration. b Temporal reproduction of total Nefzawa spring discharges (1950-2000)

The comparison of the available observed and calculated piezometric values of the CT aquifer in 1950 indicates a satisfactory model calibration with a correlation coefficient of $R^{2}=0.71$ and a root mean squared error $\sigma=3.77 \mathrm{~m}$. As shown in Fig. 14, the calculated drawdowns over the period 1951-2000 compare well to the observed ones and do not show any systematic deviation (Kriaa 2003). Finally, the temporal reproduction of the total measured spring discharge (see Fig. 13b) is considered acceptable.

The water budget (see Table 2) confirms the ongoing aquifer mining. As of the year 2000, strong changes in the hydrodynamic regime of the aquifer systems compared to the steady-state situation are calculated. The loss of water by evaporation decreases from 3.0 to $1.2 \mathrm{~m}^{3} / \mathrm{s}$. This includes water being removed by the drainage nodes inside the Chott el Djerid as well as by evapotranspiration from the phreatic aquifer. The inflow from the saline Turonian aquifer in $2000\left(4.1 \mathrm{~m}^{3} / \mathrm{s}\right)$ is 12 times the value calculated for $1950\left(0.3 \mathrm{~m}^{3} / \mathrm{s}\right)$. In the steady state, exchange through the semi-pervious clay layer intercalated between the CT and the phreatic aquifer was solely upward, i.e. from the CT towards the phreatic aquifer. In contrast, a reversed leakage from the TDS enriched phreatic aquifer to the CT amounting to $0.5 \mathrm{~m}^{3} / \mathrm{s}$ is found in the year 2000. A comparison of the $\mathrm{CT}$ and phreatic
Fig. 14 Comparison of observed vs. calculated drawdowns at observation boreholes from 1950 to 2000 . Data from five observation boreholes were available i.e. Douz, Douz North, Kebili South, El Fauoar and Nouil (see Fig.12 for the location of the observation boreholes)

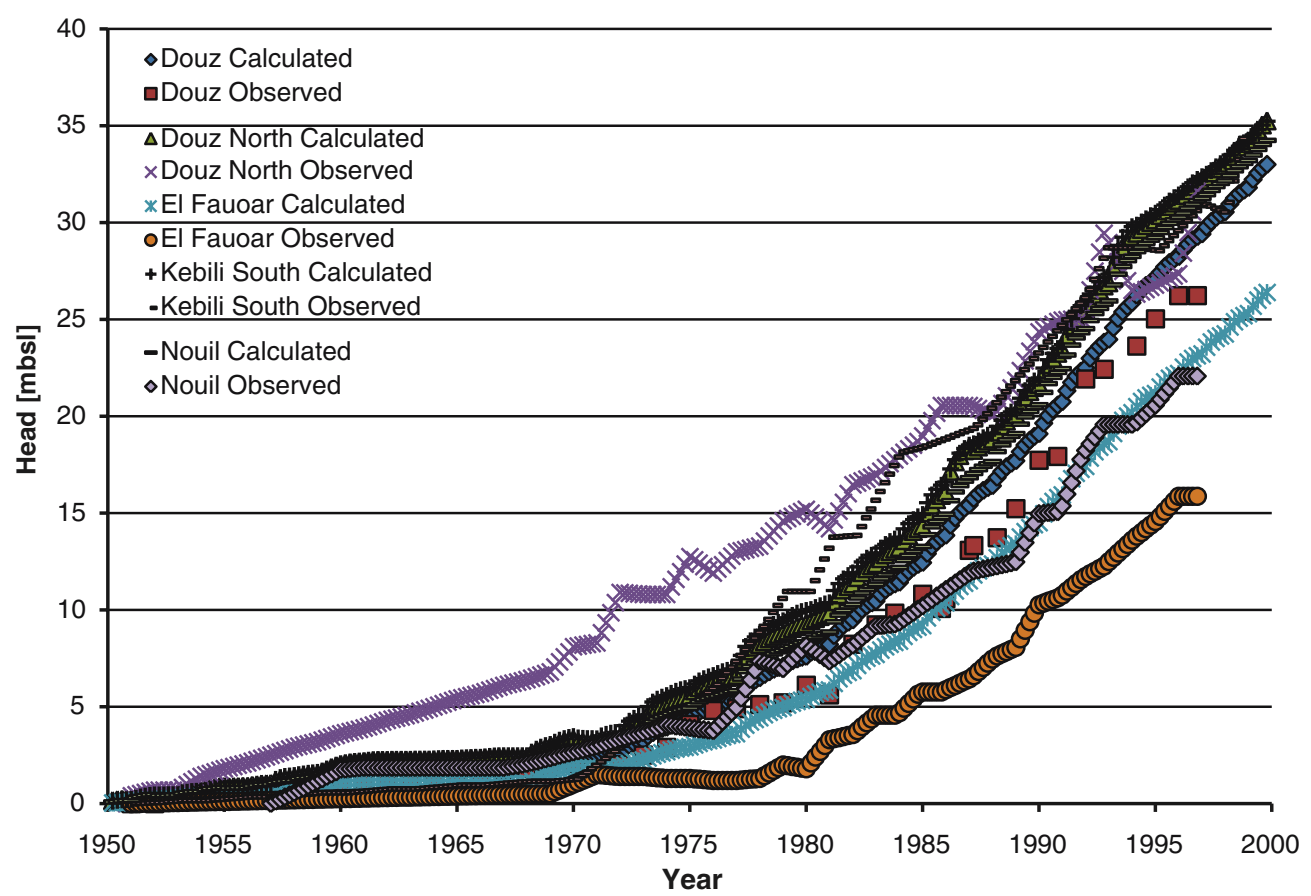


Table 2 The water balances calculated for 1950 and 2000 according to the regional flow model

\begin{tabular}{lll}
\hline Phreatic aquifer & 1950 & 2000 \\
\hline Inflow $\left(\mathrm{m}^{3} / \mathrm{s}\right)$ & & \\
Reservoir depletion & 3.15 & 1.29 \\
Exchange with CT aquifer & 0.01 & 0.45 \\
Recharge & 3.16 & 0.01 \\
Total & & 1.75 \\
Outflow (m $3 / \mathrm{s})$ & \\
Exchange with CT aquifer & 0 & 0.51 \\
Evaporation and springs & 3.05 & 1.23 \\
On-farm drainage & 0.11 & 0.01 \\
Total & 3.16 & 1.75 \\
Complexe Terminal (CT) & & \\
Inflow (m $\left.{ }^{3} / \mathrm{s}\right)$ & - & \\
Reservoir depletion & 0 & 0.66 \\
Exchange with phreatic aquifer & 4.87 & 0.51 \\
Exchange with model boundaries & 0.35 & 6.02 \\
Exchange with Turonian aquifer & 5.22 & 4.14 \\
Total & & 11.33 \\
Outflow (m $3 / \mathrm{s})$ & 3.15 & \\
Exchange with phreatic aquifer & 0.87 & 0.45 \\
Pumping & 0.72 & 9.27 \\
Exchange with model boundaries & 0.48 & 1.6 \\
Nefzawa Springs & 5.22 & 0.01 \\
Total & & 11.33 \\
\hline
\end{tabular}

aquifer piezometry in 2000 indicates that the hydraulic head of the former is still above the critical level of the Chott el Djerid. A gradient inversion in a regional sense, therefore, has not yet taken place. However, the strong drawdown caused by both the artesian and pumped wells, has slowly progressed westwards towards the Chott over the last 50 years. The future implications of this are discussed later.

\section{Transport model}

Based on the satisfactorily calibrated flow model, a transport model was built by using the modular threedimensional multi-species transport model MT3DMS (Zheng and Wang 1999). The aim was twofold: to crossvalidate conceptualization by the comparison of the historical salinity development with that calculated and to get an understanding of the future relevance of the three salinization mechanisms discussed above. For this purpose, the layers of the flow model were further discretized vertically in order to avoid instantaneous vertical mixing. The phreatic aquifer was divided into three, the CT into ten layers. The vertical and horizontal permeabilities, geometry and boundary conditions of the 13-layer model were correspondingly adopted to conform to the existing two layer flow model.

To arrive at a more or less realistic initial salinity distribution, crude but, nevertheless, representative values were assigned to each of the water bodies, fluxes as well as boundary conditions. First, a uniform CT porosity value of 0.2 was chosen. After calibration, this parameter was finally set to 0.1 over the whole domain. Calibration revealed a high model sensitivity to the CT porosity (see below). The porosity of the phreatic aquifer was uniformly set to 0.2 . The initial salinity distribution of the $\mathrm{CT}$ was taken from a 1950 map with values ranging between 1,500 and 3,000 $\mathrm{mg} / \mathrm{l}$ (UNESCO 1972). In the phreatic aquifer, the Chott region and both the oases and wadi aquifers are distinguished. In the latter, a uniform salinity of $8,000 \mathrm{mg} / 1 \mathrm{was}$ adopted corresponding to averaged observation values. In the Chott, salinity decreases gradually from $175,000 \mathrm{mg} / \mathrm{l}$ in the northwest to $10,000 \mathrm{mg} / \mathrm{l}$ on its fringes, according to actually measured concentration values (Gueddari 1980).

Information on the water quality of the Turonian aquifer is only available in the PIK and in a borehole drilled to the southeast of the Nefzawa oases region. In this borehole, a TDS of 7,000 mg/l was measured. Lacking more detailed knowledge, the boundary condition representing the Turonian aquifer was assigned a uniform TDS of 7,000 $\mathrm{mg} / \mathrm{l}$ as a fixed concentration. The same holds true for the CT boundary conditions with fixed concentrations ranging from 1,500 to $3,000 \mathrm{mg} / \mathrm{l}$. The imposed concentrations in the agricultural drains correspond to averaged observed TDS values which are regularly measured by the CRDA-Kebili. They range from $4,000 \mathrm{mg} / \mathrm{l}$ in winter to $25,000 \mathrm{mg} / \mathrm{l}$ in summer. On average, representative values are $16,000 \mathrm{mg} / \mathrm{l}$ in the Douz-El Hsay area, $12,000 \mathrm{mg} / \mathrm{l}$ in the PIK and Kebili areas and $8,000 \mathrm{mg} / \mathrm{l}$ in the other drains. In the sebkhas present in the vicinity of the oases, a TDS of $100,000 \mathrm{mg} / \mathrm{l}$ is imposed. Based on these assumptions, a more consistent initial concentration was calculated by flushing the aquifer in the undisturbed state over several thousands of years to arrive at an approximation of the state in 1950.

Subsequently, the period 1951-2000 was simulated. Figure 15 shows the results obtained in seven selected oases. These oases were chosen to be representative for the corresponding region, i.e. the area bordering the Chott el Djerid (Piezo Negga, El Fauoar 2), the PIK (Fatnassa, Ziret Louhichi), the Kebili region (Ras el Ain 4) as well as the southern part of the Nefzawa region (Douz 2 bis, El Hsay 5b). The calculated TDS values have been shifted vertically to make the first measured TDS value coincide with the calculated value. This procedure allows the calibration deviation in the reconstitution of the initial concentrations to be masked.

Generally, the transport model confirms the authors' understanding of the salinization processes in the Nefzawa region. Until now, an increase in TDS has not been of relevance in the the Chott el Djerid. That is, boreholes such as Piezo Negga in close proximity to the Chott are not yet affected by brine. However, the fingerprints of upwelling from the confining deep layers in the PIK (Ras El Ain 4) as well as backflow from agricultural drainage water (Douz 2 bis, El Hsay 5b) are visible. In the latter cases, calculated trends of TDS development are too low. This may be an indication of either underestimated fluxes in the model from the pollutant sources or an overestimation of effective porosity $n_{\mathrm{e}}$ or both. It may also be related to a conceptual aspect of the model. For the region of Douz and El Hsay, analysis of the available piezometric data indicates that the observed piezometric levels in CT boreholes located within a sector of $3 \mathrm{~km}$ in diameter vary strongly. The hydraulic head difference can reach $10 \mathrm{~m}$ 
Fig. 15 Comparison of calculated with observed TDS values for selected oases from the year 1970 to 2000 . The filled symbols are actual observations of TDS. Calculated TDS development is marked by the connected unfilled symbols. The calculated values have been shifted vertically to make them coincide with first observed TDS values. Depth to base of screen (mbgs): Fatnassa: $168 \mathrm{~m}$, Ras El Ain 4. $115 \mathrm{~m}$, Ziret Louhichi: $75 \mathrm{~m}, \mathrm{El}$ Fauoar 2: 146m, Piezo Negga: 200m, El Hsay 5b: 150m, Douz 2bis: $67 \mathrm{~m}$
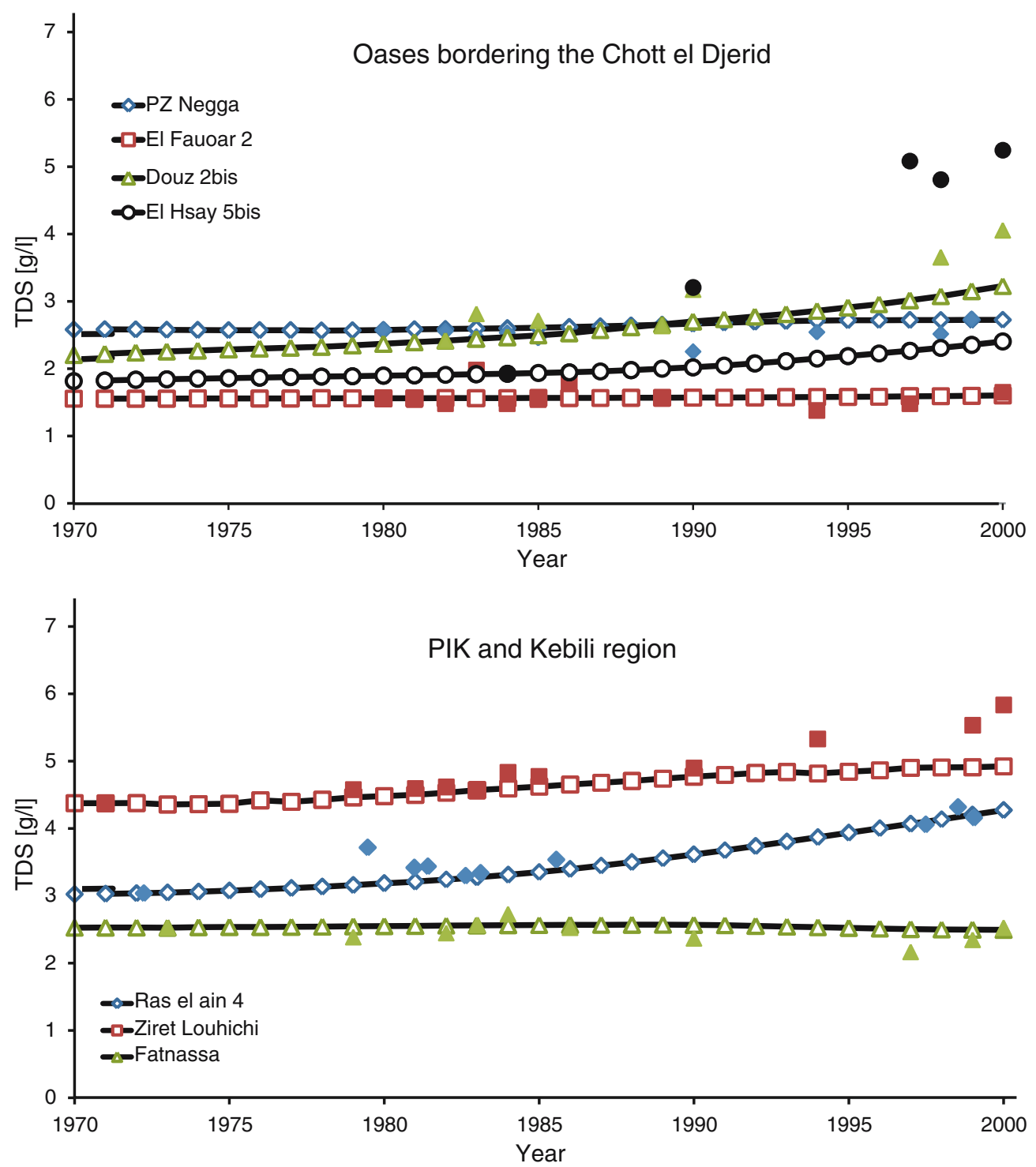

corresponding to a hydraulic gradient of $5 \times 10^{-3}$ while on average, the regional hydraulic gradient is $7.5 \times 10^{-4}$. The drilling logs show a multilayer structure of the $\mathrm{CT}$ aquifer that is composed of two chalk layers separated by a semipervious layer of marls and clayey limestones. The deeper CT wells tap the second chalk layer, whereas the shallower CT wells tap the first. This probably explains the existence of a vertical gradient of hydraulic head and concentration. Unfortunately, there are insufficient data available about the depth to the top and bottom of the screens in these boreholes to define a correlation between water salinity and the lithostratigraphic nature of the screened formation. The structural aspects of the CT and the phreatic aquifer in the Douz region remain an area for future research.

Clearly, the assumption of regionally homogeneous porosity is not wholly appropriate since the time-scales of the observed and modeled phenomena do not match in the Douz area. A local zone of a strongly decreased porosity could be introduced in the $\mathrm{CT}$ that would indicate the more clayey nature of the aquifer in this area. The calculated TDS trend would then increase naturally due to the increased transport velocity. Such modifications would also account for any unresolved variations of the conductivities of the fractured limestones. However, the lack of knowledge of the spatial distribution of effective porosity does not justify a departure from the assumption of a homogeneous regional parameter value. It has to be kept in mind that the modeling approach is regional, covering an area of more than $5,000 \mathrm{~km}^{2}$. Despite localized imperfections in the transport model, the threat to agricultural productivity due to increasing TDS in the pumped water can still be assessed for the whole of the Nefzawa.

\section{Future development}

The transport model was also used to assess the impact of the long-term application of existing and planned extrac- 
Table 3 Country-wide pumping (in $\mathrm{m}^{3} / \mathrm{s}$ ) in the CT according to withdrawal scenarios investigated

\begin{tabular}{lrlll}
\hline Year & 2000 & \multicolumn{2}{l}{2050} & \\
\cline { 3 - 5 } & & Scenario 1 & Scenario 2 & Scenario 3 \\
\hline Algeria & 20.9 & 20.9 & 20.9 & 53.6 \\
Tunisia & 14.4 & 12.2 & 12.2 & 17.7 \\
Libya & 7.4 & 7.4 & 7.4 & 18.4 \\
Total & 42.7 & 42.7 & 40.5 & 89.7 \\
\hline
\end{tabular}

tion projects on groundwater quality. For this purpose, the groundwater simulation model was extended to the year 2050 with various management alternatives modeledscenario 1: maintaining present groundwater withdrawals over the whole basin; scenario 2: decreasing present groundwater extraction in Tunisia only and scenario 3: increasing groundwater pumping over the whole CT basin according to the planned extraction projects of Algeria, Libya and Tunisia (see Table 3). In the three scenarios and over the period 2000-2050, the time-variation of the
Table 4 Summary of the fluxes (in $\mathrm{m}^{3} / \mathrm{s}$ ) in 2050 according to scenarios $(>0$ : inflow into $\mathrm{CT} ;<0$ : outflow from $\mathrm{CT})$

\begin{tabular}{llll}
\hline Fluxes & Scenario 1 & Scenario 2 & Scenario 3 \\
\hline Reservoir depletion & 1.71 & 1.18 & 6.09 \\
Phreatic aquifer & 1.09 & 0.36 & 1.98 \\
Model boundaries & 1.86 & 2.45 & -3.71 \\
Turonian aquifer & 6.32 & 4.81 & 7.58 \\
On-farm drains & 0.15 & 0.09 & 0.16 \\
Pumping & -9.27 & -7.62 & -9.37 \\
Evaporation and Aioun & -0.78 & -0.92 & -0.77 \\
$\quad$ springs & & & \\
\hline
\end{tabular}

prescribed head along the artificial domain limits is consistent with the results of the groundwater simulation model developed for the whole SASS basin (OSS 2003).

The flow model results show that the maintenance of the present pumping rates, i.e. as of the year 2000 , over the next 50 years (scenario 1) results in an average additional drawdown of $20 \mathrm{~m}$ in the Nefzawa oases
Fig. 16 TDS development from 2000-2050 according to the modeled scenarios. The filled symbols are actual observations of TDS. Calculated TDS development is marked by the connected white symbols. The calculated values have been shifted vertically to make them coincide with first observed TDS values. The TDS rise in the area bordering the Chott el Djerid is not induced by brine. Rather, it depicts the general TDS rise in the CT caused by upwelling of Turonian/CI water and backflow of agricultural drainage water
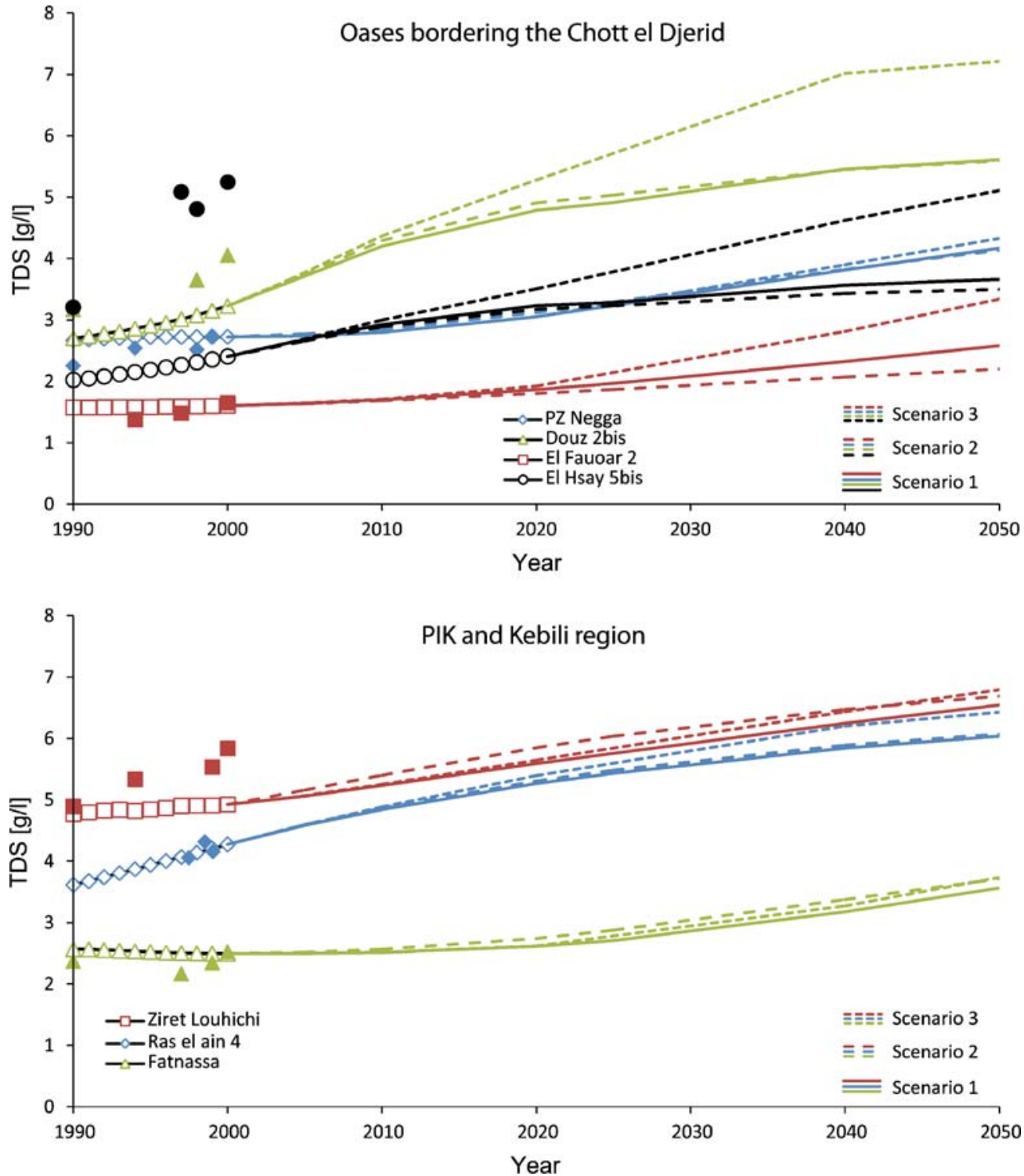
region. In the second scenario, it was assumed that irrigation water efficiency in the Nefzawa oases and the neighboring Djerid oases could be increased by $15 \%$ by means of capital investment to modernize deficient irrigation networks and technology. This could then, of course, imply a corresponding reduction of $15 \%$ in the total pumped quantity. In this case, the average additional drawdown in the Nefzawa oases region would amount to approximately $9 \mathrm{~m}$. Finally, scenario 3 explores regional effects by a cumulative increase in pumping of more than $100 \%$ over the whole CT basin. Model results in this case yield an average additional drawdown of $34 \mathrm{~m}$ in the Nefzawa oases region.

The results from the scenario analysis support the conjecture that all three pumping strategies cause a major quality deterioration of the CT waters all over the Nefzawa region (see Fig. 16). The already affected PIK (Ziret Louhichi, Ras el Ain 4) together with the Douz (Douz 2 bis, El Hsay 5b) region show an even more pronounced TDS development than the oases bordering the Chott (Piezo Negga, El Fauoar 2). According to scenario 3, CT groundwater pumped in the southern Nefzawa region will become unusable for irrigation purposes with the TDS load close to or even above $6,000 \mathrm{mg} / \mathrm{l}$ towards 2050 . In fact, it is in the southern part of the study region where, according to governmental planning, abstraction should be increased the most. Scenarios 1 and 2 do not show any significant difference in their negative influence on water quality. The reduction in pumping by $15 \%$ lowers the influx from the Turonian aquifer as well as the phreatic aquifer (Table 4). However, salinity still rises although at a lower rate; therefore, this measure is not sufficient to stabilize salinity at present levels.

\section{Conclusions}

The simulation results show that neither present nor planned pumping schemes for the Nefzawa oases region are sustainable. All scenarios investigated show a strong decline in general piezometric levels. However, the main concern is due to groundwater quality issues. All over the study area, a pronounced regional TDS increase will be observed. As in the case of the Douz region, the locally pumped CT water would have to be diluted with fresher water in order to be still suitable for irrigation purposes.

The northern part of the Nefzawa oases region and the PIK region are mainly affected by upwelling of saline waters from the CI. This process is promoted by the gradual lowering of the CT piezometric heads. Since overall pumping in the whole CT basin is responsible for this occurring, local measures of reduced pumping are only of limited effect. In contrast, in the region of Douz, backflow of drainage water is the main cause for salinization. Here, a simple back of the envelope calculation is instructive. The TDS of the pumped CT water derives from the mixture of waters from the phreatic aquifer, the CT and the Turonian aquifer. By using calculated average fluxes and concentrations of the individual contributions, it is easy to show that a $50 \%$ reduction of drainage water backflow would cause a TDS reduction in the pumped water of $21 \%$. A backflow reduced by $75 \%$ would lead to a TDS reduction of $32 \%$ and would result in an average concentration of $3,500 \mathrm{mg} / \mathrm{l}$ in the pumped CT water. Evidently, the replacement of the traditional furrow irrigation by PVC tubes, a switch to precise irrigation practices as well as removal of drainage water from the area, are effective measures to stabilize TDS values.

The transport model results revealed problems in the southeastern part of the model. Sensitivity analysis showed the importance of the effective porosity parameter on results. Model results could certainly be improved by better knowledge of the distribution of this parameter. All over the Nefzawa oases region, salinity measurements at various depths would give important information about the characteristics of the vertical salinity gradient.

Control measures to limit CT salinization would include the following. First, planned extraction projects in the south of the Nefzawa region have to be abandoned. Second, pumping will have to be significantly reduced within the oases and the extension of the irrigated perimeters halted so as to minimize the contamination risk from the sources of salinity discussed above. Legal regulation could help to avoid a further increase of groundwater utilization by private farmers which is not subject to governmental planning. Third and finally, increasing irrigation efficiency as well as the implementation of effective drainage measures should go hand in hand with a strategy of moderation. From today's perspective, it seems inescapable that CT pumping will have to be relocated to more distant places over the course of time and the pumped water subsequently conveyed to the fertile oases soils.

Acknowledgements The authors wish to acknowledge Dr. B. Ben Baccar and Prof. M. Besbes for their valuable help and comments in the data analysis. The comments of three anonymous reviewers were greatly appreciated. Tobias Siegfried and Tobias El-Fahem were partially supported by the Alliance for Global Sustainability (AGS).

\section{References}

ARMINES and Ecole Nationale d'Ingénieurs de Tunis (ENIT) (1984) Modèle mathématique du Complexe Terminal NefzawaDjérid [Mathematical model of the Complexe Terminal, Nefzawa-Djérid]. Ministère de l'Agriculture, Tunis

Ben Dhia H, Bouri S (1995) Overview of geothermal activities in Tunisia. Paper read at World Geothermal Conference 1995, Florence, May 1995

Besbes M, Abdous B, Abidi B, Ayed A, Bachta M, Babasy M, Ben Baccar B, El Batti D, Ben Salah Y, Charreton MB, Biout F, Douma A, Fezzani C, Gadhi M, Horriche F, Kadri S, Khadraoui A, Khanfir R, Kinzelbach W, Larbes A, Latrech D, Margat J, De Marsily G, Mamou A, El Mejerbi M, Mekrazi A, Mhiri A, Moumni L, Nanni M, Pallas P, Pizzi G, Salem A, Salem OM, Taibi R, Zammouri M (2003) The northwestern Sahara aquifer system: joint management of a transborder basin. Houille Blanche-Rev Int Eau 5:128-133

Chiang W-H, Kinzelbach W (2001) 3D-groundwater modeling with PMWIN a simulation system for modeling groundwater flow and pollution. Springer, Berlin 
Direction Générale des Resources en Eau (2000) Annuaire de la piézométrie des nappes de Tunisie [Piezometric inventory of the aquifers in Tunisia]. Ministère de l'Agriculture, Tunis

Edmunds WM, Shand P, Guendouz AH, Moulla AS, Mamou A, Zouari K (1997) Recharge characteristics and groundwater quality of the grand Erg oriental basin. British Geological Survey, Keyworth, Nottingham

El-Fahem T (2003) Salinisation of groundwater in the Nefzaoua Oases: South Tunisia, Institute of Hydromechanics and Water Resources Management, Swiss Federal Institute of Technology, Zürich

Food and Agricultural Organization (FAO) (2005) FAOSTAT. Food and Agricultural Organization. http://faostat.fao.org/. Cited 16 April 2007

Gardner G (1996) Shrinking fields: cropland loss in a world of eight billion. Worldwatch paper no. 131. In: Worldwatch papers. The Worldwatch Institute, Washington, DC

Ghassemi F, Jakeman AJ, Nix HA (1995) Salinisation of land and water resources: human causes, extent, management and case studies. CABI, Wallingford, UK

Gueddari M (1980) Géochimie des sels et des saumures du Chott el Djérid [Geochemistry of salts and brines from the Chott el Djerid], Univ. de Paul Sabatier, Toulouse, France

Harbaugh AW, Banta ER, Hill MC, McDonald MG (2000) Modflow-2000, the U.S. geological survey modular ground-water model: user guide to modularization concepts and the groundwater flow Process. US Geological Survey, Reston, VA, USA

Hillel D (2000) Salinity management for sustainable irrigation: integrating science, environment and economics. In: Bank TW (ed) Environmentally and socially sustainable development: rural development. The World Bank, Washington, DC

International Atomic Energy Agency (IAEA) (2001) Global network for isotopes in precipitation. The GNIP database. IAEA, Vienna

Kbir-Ariguib N, Chehimi DB, Zayani L (2001) Treatment of Tunisian salt lakes using solubility phase diagrams. Pure Appl Chem 73(5):761-770

Kriaa S (2003) Contribution à l'étude de la qualité des eaux de la nappe du Complexe Terminal dans la Nefzaoua [Contribution to the study of the Complexe Terminal water quality in the Nefzawa], Ecole Nationale d'Ingenieurs de Tunis, Tunis

Mamou A (1990) Caractéristics et évaluation des ressources en eau $\mathrm{du}$ sud Tunisien [Characteristics and evaluation of the water resources in southern Tunisia]. PhD Thesis, Université du ParisSud Centre d'Orsay, Paris

Mamou A, Hlaimi A (1999a) Les nappes phréatiques de la Nefzaoua. Direction Générale des Ressources en Eau. Ministère de l'Agriculture, Tunis
Mamou A, Hlaimi A (1999b) Les nappes phréatiques de la Nefzaoua [Phreatic groundwater in the Nefzawa oases]. Direction Générale des Ressources en Eau. Ministère de l'Agriculture, Tunis

Meckelein W (1977) Geographische Untersuchungen am Nordrand der tunesischen Sahara [Geographical investigations on the northern fringe of the Tunisian Sahara]. Stuttgarter Geographische Schriften, Stuttgart, Germany, pp 247-301

Observatoire du Sahara et du Sahel (OSS) (2003) The North West Sahara aquifer system: joint management of a transborder basin. OSS, Tunis

Perennes J-J (1993) L'eau et les hommes au Maghreb: Contribution d'une politique de l'eau Mediterranee [Water and people in the Maghrib: contribution to a Mediterranean water policy]. Karthala, Paris

Pouget M (1966) Etude pédologique des oasis de la PIK et du groupe Mansoura [Soil study in the PIK oases and the Mansoura group]. Direction Generale des Resources en Eau. Ministère de l'Agriculture, Tunis

Swezey CS (1996) Structural controls on Quaternary depocentres within the Chotts Trough region of southern Tunisia. J Afr Earth Sci 22(3):335-347

The World Bank Group (2004) Countries and regions. The World Bank Group, Washington, DC

United Nations Educational Scientific and Cultural Organization (UNESCO) (1972) Etude des Ressources en Eau du Sahara Septentrional [Study of the water resources in the north-western Sahara]. Final report and appendixes. In: ERESS, UNESCO, Paris

Whittemore DO (1984) Geochemical identification of salinity sources. In: French RH (eds) Salinity in watercourses and reservoirs (Proceedings of the International Conference on State-of-the-Art Control of Salinity). Butterworth, Stoneham, MA, USA

Whittemore DO (1988) Bromide as a tracer in ground-water studies: geochemistry and analytical determination. In: Proceedings ground water geochemistry conference, National Water Well Association. Dublin, OH, USA

World Health Organization-United Nations Environment Programme (WHO-UNEP) (1989) In: Meybeck M, Chapman D, Helmer R (eds) Global fresh-water quality: a first assessment. Blackwell, Oxford

Zheng C, Wang PP (1999) A modular three-dimensional multispecies transport model for simulation of advection, dispersion and chemical reactions of contaminants in groundwater systems; documentation and user's guide. In: SERDP-99-1. Contract report, US Army Engineer Research and Development Center, Vicksburg, MS 